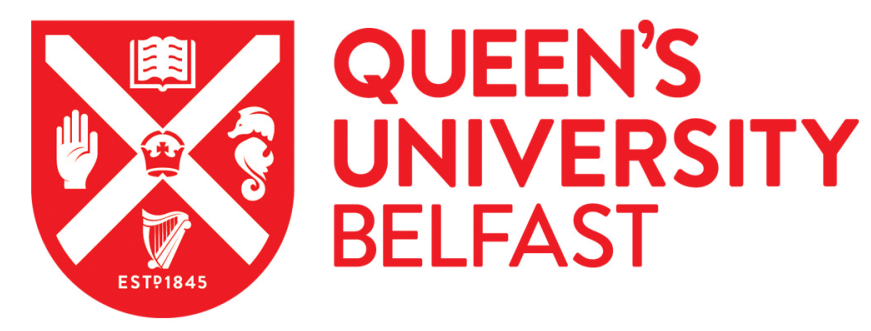

\title{
CSF biomarkers in delirium a systematic review
}

Hall, R. J., Watne, L. O., Cunningham, E., Zetterberg, H., Shenkin, S. D., Wyller, T. B., \& MacLullich, A. M. J. (2017). CSF biomarkers in delirium a systematic review. International Journal of Geriatric Psychiatry. https://doi.org/10.1002/gps.4720

\section{Published in:}

International Journal of Geriatric Psychiatry

\section{Document Version:}

Peer reviewed version

Queen's University Belfast - Research Portal:

Link to publication record in Queen's University Belfast Research Portal

\section{Publisher rights}

Copyright ( 2017 John Wiley \& Sons, Ltd.This work is made available online in accordance with the publisher's policies. Please refer to any applicable terms of use of the publisher.

\section{General rights}

Copyright for the publications made accessible via the Queen's University Belfast Research Portal is retained by the author(s) and / or other copyright owners and it is a condition of accessing these publications that users recognise and abide by the legal requirements associated with these rights.

Take down policy

The Research Portal is Queen's institutional repository that provides access to Queen's research output. Every effort has been made to ensure that content in the Research Portal does not infringe any person's rights, or applicable UK laws. If you discover content in the Research Portal that you believe breaches copyright or violates any law, please contact openaccess@qub.ac.uk. 


\section{CSF biomarkers in delirium: A systematic review}

Roanna J Hall MRCP(UK) $\mathrm{PhD}^{1,2 *}$, Leiv Otto Watne MD $\mathrm{PhD}^{3,4 *}$, Emma Cunningham MRCP(UK) $\mathrm{PhD}^{5}$, Henrik Zetterberg MD PhD ${ }^{6,7,8}$, Susan D Shenkin FRCP (Edin) MD ${ }^{1,2}$, Torgeir Bruun Wyller MD PhD ${ }^{3,9}$, Alasdair MJ MacLullich MRCP(UK) PhD ${ }^{1,2}$

1) Edinburgh Delirium Research Group, Geriatric Medicine, University of Edinburgh, Scotland

2) Centre for Cognitive Ageing and Cognitive Epidemiology, University of Edinburgh, Scotland

3) Oslo Delirium Research Group, Department of Geriatric Medicine, Oslo University Hospital, Norway

4) Institute of Basic Medical Sciences, University of Oslo, Norway

5) Centre for Public Health, Queen's University of Belfast, Northern Ireland

6) Clinical Neurochemistry Laboratory, Sahlgrenska University Hospital, Mölndal Sweden

7) Department of Neuroscience and Physiology, Department of Psychiatry and Neurochemistry, the Sahlgrenska Academy at the University of Gothenburg, Mölndal, Sweden

8) Department of Molecular Neuroscience, UCL Institute of Neurology, Queen Square, London, UK

9) Institute of Clinical Medicine, University of Oslo, Norway

*RH and LOW contributed equally to this work.

Running head: CSF biomarkers in delirium 
Key words: delirium pathophysiology, CSF biomarkers, neuroinflammation

\section{Key points:}

1. Delirium is a major public health concern, and research on pathophysiological mechanisms is urgently needed.

2. Some biochemical changes in the brain are to an extent reflected in the cerebrospinal fluid (CSF) and in recent years there has been a blossoming of studies examining CSF as a method of studying the pathophysiology of delirium.

3. The 22 studies identified in this review reveal a small but growing literature, in which many of the important hypotheses in delirium pathogenesis have been examined, but from which few firm conclusions can currently be drawn. Nevertheless, the overall interpretation of the literature supports the vulnerable brain concept.

4. A concerted effort is now required to standardise several aspects of the methodology and reporting of these studies, in order to advance this highly promising direction in delirium research.

Funding: The Norwegian Association for Public Health

\section{Word count: 4670}

Corresponding author: Leiv Otto Watne, Oslo University Hospital, PB 4950 Nydalen, N-0424 Oslo, Norway. Tel +47 40203712. Email: 1.o.watne@gmail.com. 


\begin{abstract}
Objective In recent years there has been a blossoming of studies examining cerebrospinal fluid (CSF) as a method of studying the pathophysiology of delirium. We systematically reviewed the literature for CSF studies in delirium and provide here a summary of the implications for our understanding of delirium pathophysiology. We also summarise the methods used for CSF analysis and discuss challenges and implications for future studies.
\end{abstract}

Methods In this systematic review we screened MEDLINE, EMBASE, PsycINFO, Web of Science, PubMed and the Cochrane Library for articles on CSF biomarkers in delirium, published to September $3^{\text {rd }}$ 2016. Studies were required to use DSM or ICD criteria for delirium, or a validated tool. We excluded case reports. There were no other restrictions on study type.

Results We identified 3280 articles from our initial search and 22 articles were included in this review. All studies were prospective, including over 400 patients with delirium and 700 controls. More than 70 different biomarkers were studied. Studies could not be compared with each other for meta-analysis because of their heterogeneity, and varied widely in their risk of bias and quality assessments.

Conclusions The 22 studies identified in this review reveal a small but growing literature, in which many of the important hypotheses in delirium pathogenesis have been examined, but from which few firm conclusions can currently be drawn. Nevertheless, the overall interpretation of the literature supports the vulnerable brain concept, that is that biomarker 
evidence of for example Alzheimer's disease pathology and/or neuroinflammation is associated with delirium. 


\section{Introduction}

Delirium is a common, serious and dramatic complication of acute medical illness associated with increased mortality and morbidity (Inouye et al., 2013, Witlox et al., 2010). Recent evidence suggests that delirium predicts dementia in previously cognitively intact patients, and is linked with accelerated decline in those with existing dementia (Davis et al., 2012, Krogseth et al., 2016, Davis et al., 2017). Thus, delirium is a major public health concern, and research on pathophysiological mechanisms is urgently needed.

In recent years there has been a blossoming of studies examining cerebrospinal fluid (CSF) for insights into the pathophysiology of delirium. CSF, a clear fluid surrounding the brain and providing mechanical support, also carries nutrients and signalling molecules to neurons and helps the clearance of metabolites into the blood (Johanson et al., 2008, Louveau et al., 2015). The main advantage utilising CSF to measure markers of central nervous system (CNS) changes is that it communicates freely with the brain interstitial fluid that bathes the neurons. Some biochemical changes in the brain are thus reflected in the CSF, which may be regarded as an accessible, albeit imperfect, sample of the brain interstitial fluid (Blennow et al., 2010). This provides an advantage over blood, as confirmed in studies of neurodegenerative disorders (Blennow et al., 2010). Further, CSF has low protease activity and most molecules do not change upon sampling if the sample is uncontaminated by blood (Johanson et al., 2008). The main disadvantage is that lumbar puncture (LP) is an invasive procedure, and there are obvious ethical and practical difficulties in obtaining CSF specimens for research purposes from patients with delirium. Several recent CSF delirium studies have overcome this problem by exploiting the valuable opportunity afforded by spinal anaesthetic administration for surgical procedures, especially hip fracture surgery. 
In 2011, Hall et al published a systematic literature review of the eight existing studies of CSF in delirium(Hall et al., 2011). The 2011 review highlighted a paucity of research in this area; no clear conclusions emerged regarding delirium pathophysiology, with more detailed studies needed. This review serves as an update. We aimed to identify the current published literature examining CSF in delirium, and ask, do CSF biomarker concentrations relate to delirium incidence, severity, duration or subtype. We summarise what the current literature reveals about delirium pathophysiology, and also the methods used for CSF analysis and discuss challenges and implications for future studies. 


\section{Methods}

\section{Search strategy and selection criteria}

We are reporting this systematic review according to the PRISMA guidelines (Liberati et al., 2009). We searched MEDLINE, EMBASE, PsycINFO, Web of Science, PubMed and the Cochrane Library for studies published in English or Norwegian to September $3^{\text {rd }} 2016$. Additionally we hand searched the bibliographies of relevant articles, performed a forward citation search in Web of Science for all studies examined, and contacted experts in the field via the European Delirium Association. We used terms including Delirium or Acute Confusional State, and Cerebrospinal Fluid or Lumbar Puncture (see Appendix 1 for full search strategy and Appendix 2 for the study protocol).

Inclusion criteria were (i) that delirium was diagnosed by Diagnostic and Statistical Manual of Mental Disorders (DSM III; DSM IIIR; DSM IV, DSM 5) or International Classification of Diseases (ICD) criteria, or a method based upon this and (ii) that we could extract data on biomarker findings in CSF in delirium. Exclusion criteria were (i) case reports (no other restrictions on study type) and (ii) studies involving delirium tremens or hepatic encephalopathy, or where neuropsychiatric Systematic Lupus Erythematosus was the primary cause of delirium.

Data extraction and assessment of study quality and risk of bias

RJH and LOW independently performed the search and identified articles for full text review. Included studies were agreed by consensus and data were extracted by RJH, LOW and EC. We recorded (a) study design and provenance, (b) number and characteristics of patients and controls and comparability of patient and control groups, (c) method used to diagnose 
delirium, (d) delirium severity, motor subtype and duration, (e) aetiology of delirium, (f) presence and method of assessment for underlying dementia, (g) method of obtaining CSF, (g) biomarkers studied, (i) preanalytical and analytical laboratory methodology (j) main study findings, (k) statistical significance, and (l) statistical methods. Risk of bias was assessed according to the RoBANS tool (Kim et al., 2013), with pre-determined criteria for low or high risk for each domain. We considered the principal confounding factor to be dementia. Risk of bias was assessed by RJH, LOW and EC independently, and agreed by consensus. 


\section{Results}

We identified 3280 articles from our initial search and 2352 remained after removal of duplicates (Figure 1). 194 full-text articles were assessed for eligibility (Appendix 3), and 22 articles were included in the systematic review. The included articles reported data from nine research groups, including several collaborations (Table 1). All studies collected data on delirium status prospectively, although most collected CSF only once (with the exception of (Koponen and Riekkinen, 1990) and (Hirsch et al., 2016). Over 400 patients with delirium and 700 controls were studied, although many are included in more than one article. There is some overlap of biomarkers studied by different research groups, and the differing results are discussed. Studies could not be compared to each other for meta-analysis due to study heterogeneity. Baseline characteristics of the included studies are presented in Table 1, the main findings in Table 2, and the results of the risk of bias assessment plus additional quality comments in Table 3. Several studies examined biomarker relationships with delirium severity, few assessed motor subtype and none reported delirium duration. Overall, risk of bias varied, with smaller exploratory studies generally having higher risk, and more recent larger studies lower risk. Many had a risk of selection bias, limited control of confounding variables and inadequate blinding of outcome assessments. Risk of publication bias was difficult to assess as other biomarkers may have been measured and not reported. Studies generally measured delirium well, and reported all their outcome variables. Details of the methods reported are summarized in Supplementary Table 1. A narrative summary of the findings is presented below.

[insert Figure 1 , Table 1 and Table 2 around here] 


\section{Risk markers of delirium}

Dementia neuropathology markers

Dementia neuropathology markers were measured in three studies of patients undergoing orthopaedic surgery.

Witlox et al examined $\beta$-amyloid1-42 (A $\beta 42)$, total-tau (T-tau) and phosphorylated tau (P-tau) in hip fracture patients (Witlox et al., 2011). There were no statistically significant differences in levels of these markers between those with or without post-operative delirium (preoperative delirium was excluded).

Idland et al also studied hip fracture patients (Idland et al., 2016). They found that, in patients without dementia, delirium was associated with lower CSF A $\beta 42$ levels and higher T-tau levels and lower ratios of A $\beta 42$ to t-tau and p-tau. In patients with dementia, CSF biomarker levels did not differ between those with and without delirium. The authors suggest that a possible explanation for the discrepancy with Witlox et al is that the biomarker levels in the Dutch cohort were much closer to normal levels, indicating less AD pathology.

Xie et al studied elective arthroplasty patients (Xie et al., 2014). They found no significant difference in CSF A $\beta 42 /$ tau ratio or $A \beta 40 /$ tau ratio between groups with and without delirium. When they examined quartiles of the $A \beta /$ tau ratios, they found a higher incidence of delirium in those in the lowest quartile for both ratios.

\section{Disease markers of delirium}

\section{Neurotransmitters and hormones}


Levels of neurotransmitter precursors, metabolites and metabolising enzymes, and potentially neuroactive hormones have been measured in several studies, although few have been analysed in more than one study.

Somatostatin-like immunoreactivity (SLI) and Beta-endorphin-like immunoreactivity (BLI)

The first CSF study was published in 1990 (Koponen and Riekkinen, 1990). An aetiologically heterogeneous group of older patients with delirium underwent a morning fasting LP on the day following their index admission, at two weeks after admission, and at one year and four years. Their control group was from a Healthy Ageing study. For the whole delirium group, they found a reduction in mean SLI level at index, two weeks, one year and four years (Koponen et al., 1994b) and a reduction in mean BLI at index, two weeks and one year(Koponen and Riekkinen, 1990).

\section{Monoamine precursors and metabolites}

Koponen et al found that the principal serotonin metabolite 5-hydroxyindoleacetic acid (5HIAA) was higher in the subgroups with delirium superimposed on vascular dementia or no CNS disease(Koponen et al., 1994c). The levels stayed high at two weeks and one year in both groups.

Watne et al published analyses of 5-HIAA and aromatic amino acids, which are precursors for monoamines(Watne et al., 2016). They found that both phenylalanine and tyrosine (dopamine and noradrenaline precursors) and tryptophan (serotonin precursor) were higher in patients with delirium. In patients without dementia, 5-HIAA was also highest in delirium, paralleling 
the increase in tryptophan. Patients with dementia had lower levels of most amino acids compared to patients without dementia. Analyses stratified by dementia status, however, revealed that delirium was associated with higher levels of the same amino acids in both strata. Notably, the correlation between serum and CSF amino acids levels was poor.

Ramirez-Bermudez et al examined homovanillic acid (HVA, a dopamine metabolite) in a cohort of patients with acute neurological symptoms requiring LP for a clinical indication (Ramirez-Bermudez et al., 2008). This cohort was younger and had a high proportion of CNS infections (43/51 patients), and HIV infection (16/51 patients). Although HVA was not significantly different between those with and without delirium, it was higher in patients with psychotic features such as hallucinations and delusions.

\section{Acetylcholine}

Koponen et al found no association between delirium and acetylcholinesterase (AChE), the principle enzyme responsible for metabolising acetylcholine (Koponen et al., 1994a) in the delirious group as a whole. However, there was a fall in levels of AChE between the twoweek and one year time-points in the delirium subgroups with $\mathrm{AD}$, multi-infarct dementia and hyperkinetic delirium, and a small but non-significant reduction in levels of AChE in the group with no CNS disease. Watne et al analysed anticholinergic activity (AA) in patients with acute hip fracture from Oslo and Edinburgh(Watne et al., 2014) and found that AA was not significantly different in delirium.

\section{Cortisol}


Pearson et al found cortisol levels to be higher in those with delirium than those without, in a small cohort of patients with acute hip fracture (Pearson et al., 2010).

\section{Inflammation}

Neuroinflammation has been assessed in several studies. All studies included orthopaedic patients (hip fracture in all except for elective surgery in Hirsch (Hirsch et al., 2016)).

\section{Cytokines and chemokines}

MacLullich et al measured six cytokines, but only interleukin (IL) -8 (33/36 samples) and IL6 (3/36 samples) were above the detection limit (MacLullich et al., 2011). IL-8 was higher in patients with delirium at any stage.

Westhoff et al measured 41 different cytokines and chemokines but only 16 were detectable in more than $50 \%$ of the samples (Westhoff et al., 2013). Fms-like tyrosine kinase-3 (Flt-3L), IL-1ra and IL-6 were significantly lower in patients with postoperative delirium (preoperative delirium was excluded). They detected, but found no difference in levels of, IL-8. The authors suggest that the findings could be interpreted that delirium is the result of a dysfunctional inflammatory state, where reduced anti-inflammatory mediators play a more important role than an increased pro-inflammatory activity.

Cape et al measured several inflammatory markers and a marker of astroglial activation (Glial Fibrillary Acidic Protein, GFAP) in patients recruited in Edinburgh and Amsterdam (Cape et 
al., 2014). The investigators found that IL-1 $\beta$ was elevated in those with incident delirium, and IL-1ra was elevated in prevalent delirium. The CSF:serum ratio of IL-1 $\beta$ was higher in the delirium group. GFAP was not significantly different between groups. IFN- $\gamma$ and IGF-1 were not detected in CSF and IL-1 $\beta$ was detected in low concentrations. This study supports a role for the IL-1 family in delirium. The higher CSF:serum ratio of IL-1 $\beta$, with no correlation between the two, suggests a CNS source of IL-1 $\beta$.

Neerland et al examined C-reactive protein (CRP), IL-6 and soluble IL-6 receptor (sIL-6R). In patients without prefracture cognitive impairment, CSF CRP was higher in delirium (Neerland et al., 2016). There were no significant differences in delirium in IL-6 or sIL-6R. The authors suggest that different pathophysiological mechanisms are important in different subgroups of patients. In particular, neuroinflammation may be more important in cohorts other than those with hip fracture.

A recent study reported longitudinal changes in CSF and plasma in ten patients undergoing elective knee surgery (Hirsch et al., 2016). An indwelling spinal catheter was placed at the time of spinal anesthesia and removed after 24 hours. Plasma and CSF were collected preoperatively and at three, six and 18 hours postoperatively. Only one patient developed delirium, and CSF levels of the pro-inflammatory cytokines IL-6, IL-8 and monocyte chemotactic protein (MCP)-1 showed a persistent increase in this patient. Intriguingly, levels of several pro- and anti-inflammatory cytokines changed significantly postoperatively compared to baseline, and these changes were often more pronounced in CSF than plasma. 
Neopterin, a biomarker of cell-mediated immunity and oxidative stress, has been measured in one study (Hall et al., 2016). Those who developed delirium after hip fracture had higher levels compared to those who did not become delirious. Neopterin levels were highest in patients with delirium superimposed on dementia and lowest in patients free from both conditions. The authors conclude that these findings support the neuroinflammation hypothesis in delirium, and that delirium and dementia may have an additive effect.

\section{Blood-cerebrospinal fluid barrier}

Hov et al assessed the blood-cerebrospinal fluid barrier integrity in hip fracture patients with Q-albumin (the ratio of CSF albumin to serum albumin) (Hov et al., 2016). The majority of patients $(88 \%)$, had intact blood-cerebrospinal fluid barrier integrity, but all patients with barrier dysfunction $(n=14)$ had delirium $(n=11)$ or subsyndromal delirium $(n=3)$. The authors conclude that blood-cerebrospinal fluid barrier dysfunction might be important for delirium, but it is not a prerequisite for delirium to develop.

\section{Proteomics}

Poljak et al recruited patients in two centres, Sydney (medical patients) and Edinburgh (hip fracture patients) (Poljak et al., 2014). Of the 273 proteins identified, 16 were dysregulated in eight or more delirium subjects across both cohorts. Several proteins involved in the inflammatory response were also upregulated in the majority of those with delirium.

Another proteomics study (Westhoff et al., 2015) included two different Dutch cohorts with acute hip fracture (preoperative delirium was excluded), for derivation and validation of 
changes found with proteomics. Of the 17 proteins identified as different in the proteomics analysis between those with and without delirium, none were confirmed as different with immunoassay in the validation cohort.

\section{End products of delirium}

\section{Markers of neuronal cell death}

Elderly medical patients with prolonged delirium and a control group of outpatients with AD but no delirium were studied in (Caplan et al., 2010). CSF lactate, protein, glucose, S100 calcium-binding protein B (S100B, a marker of CNS injury and astrogliosis) and neuronspecific enolase (NSE) were measured. They found higher CSF lactate in the delirium group, lower NSE, higher protein, and no difference in S100B and glucose. Of note, the group with delirium was acutely unwell compared to the outpatient dementia group; therefore differences may be due to the general effects of acute illness rather than delirium.

S100B has also been measured in hip fracture patients in two different studies. Hall et al found that S100B concentrations were higher in those with preoperative delirium, although there was no difference between those with and without delirium at any stage during the perioperative period (Hall et al., 2013). Another found no significant difference in S100B between patients with or without (predominantly postoperative) delirium (Beishuizen et al., 2015). 


\section{Discussion}

The 22 studies identified in this review reveal a small but growing literature, in which many of the important hypotheses in delirium pathogenesis have been examined, but from which few firm conclusions can currently be drawn. The observational nature of all studies means causality cannot be established. The populations studied are heterogeneous, and studies varied in their risk of bias. We will now briefly discuss what this literature suggests regarding delirium pathophysiology.

\section{Risk markers}

Dementia is one of the strongest risk factors for delirium (Ahmed et al., 2014, Fong et al., 2015). However, of the three studies that examined whether levels of established CSF markers for dementia were associated with risk of delirium only Idland et al showed a convincing relationship (Idland et al., 2016). These findings may be related to the presence of incipient dementia, and future studies should take this into account.

\section{Disease markers of delirium}

Several of the studies support the hypothesis of neurotransmitter imbalance in delirium. The monoamines (dopamine, serotonin, noradrenaline) have important roles in attention and cognition, cognitive domains affected in delirium (Maldonado, 2013). The results in (Koponen et al., 1994c) support an excess of serotonin in delirium. The findings of increased levels of precursor amino acids in (Watne et al., 2016) suggest a downstream role for serotonin and for a generally higher monoaminergic tone in delirium. The association of high 
dopamine metabolites with psychotic features in (Ramirez-Bermudez et al., 2008) supports a role in these symptoms of delirium, if not the whole syndrome. These findings have potential therapeutic implications and replication studies would be valuable.

Loss of somatostatin signaling appears to have a role in dementia and transient loss may be implicated in delirium (Koponen et al., 1994b). There may be a fall in beta-endorphin signaling in delirium, but it is difficult to conclude that these changes are related to delirium rather than dementia (Koponen and Riekkinen, 1990).

The findings in (Pearson et al., 2010) support the hypothesis that delirium is associated with elevated CNS cortisol levels.

The neuroinflammatory hypothesis of delirium is a leading hypothesis, whereby a brain made vulnerable by neurodegenerative disease or ageing responds to peripheral inflammatory stimuli with a greater central inflammatory response, manifesting in exaggerated sickness behavior and delirium(Cunningham and Maclullich, 2013). In order to test this hypothesis in human studies, animal modelling (Cunningham et al., 2005, Godbout and Johnson, 2006) and hypothesis papers(Cerejeira et al., 2010) would predict that CSF IL-1, IL-6 and TNF- $\alpha$ should be elevated and IL-10 should be reduced in delirium. Elevated IL-1 $\beta$ was found in (Cape et al., 2014), with a higher ratio in CSF:serum, but it was not detected in (MacLullich et al., 2011) nor (Westhoff et al., 2013). Since IL-1 $\beta$ is often hard to detect, its endogenous antagonist IL-1ra could be seen as a marker of recent IL-1 $\beta$ activity, as it is usually released after IL-1 $\beta$ to limit the inflammatory response(Allan et al., 2005). Westhoff et al found lower CSF IL-1ra levels in those about to develop delirium, whereas Cape et al found higher CSF IL-1ra levels in those with active delirium, possibly indicating that a lower baseline level increases the risk of developing delirium whereas during active delirium the higher levels may indicate either an endogenous response to an initial spike of IL-1 $\beta$ or a neuroprotective 
response to the insult of delirium or the inflammatory and traumatic response. IL-6 was reduced in (Westhoff et al., 2013), not significantly different in (Neerland et al., 2016), and elevated in the sole patient with delirium in the Hirsch longitudinal study(Hirsch et al., 2016). TNF- $\alpha$ and IL-10 were both not detected in (MacLullich et al., 2011), and not significantly different (in small numbers) in (Westhoff et al., 2013). More indirectly the findings of the Poljak proteomics analysis that several of the proteins involved in the inflammatory response are upregulated in delirium also supports this notion(Poljak et al., 2014) and the finding by (Hall et al., 2016) that neopterin is highest in delirium superimposed on dementia lend some support to the idea that peripheral inflammatory insults may lead to an exaggerated central inflammatory response. However, the Westhoff proteomics study highlights the difficulties in this research area, with none of the candidate findings validated(Westhoff et al., 2015).

Examining the evidence so far, one does not find a great deal to support the neuroinflammatory hypothesis of delirium, however it has not been refuted and many of the studies examining the key biomarkers have been small, with low detection levels. Delirium aetiology, timing of CSF sampling and underlying dementia neuropathology are potential reasons for the conflicting findings in the published literature.

\section{End products of delirium}

The finding of raised CSF lactate suggests that a disruption of the brain's normal aerobic metabolism, perhaps resulting from ischaemia or hypoglycaemia, may be involved in delirium (Caplan et al., 2010). S100B was found to be elevated in those with active delirium after hip fracture (Hall et al., 2013), but not in medical patients with active delirium compared to 
patients with dementia who were not acutely unwell (Caplan et al., 2010), nor in a third study in hip fracture patients with predominantly post-operative delirium (Beishuizen et al., 2015). In the latter study, the highest levels were in those with active delirium, highlighting that timing of sampling may be crucial. It is therefore unclear whether delirium is associated with astrigliosis or CNS damage. NSE was also lower in patients with delirium, contradicting such a hypothesis.

[insert Table 3 around here]

Delirium severity, subtype and timing of sampling

Increasing delirium severity was associated with lower A $\beta 40 /$ tau and A $\beta 42 /$ tau ratios(Xie et al., 2014), higher HVA(Ramirez-Bermudez et al., 2008), lactate and NSE levels(Caplan et al., 2010). In those without prior cognitive impairment, higher anticholinergic activity (Watne et al., 2014)and higher neopterin levels(Hall et al., 2016) were also associated with more severe delirium. There were no clear relationships between any of the biomarkers and delirium subtype. Timing of CSF sampling according to different phases of delirium was associated with different biomarker findings. CSF collection before delirium was associated with reduced IL-6, IL-1ra, Flt-3L(Westhoff et al., 2013), increased IL-1ß(Cape et al., 2014), neopterin(Hall et al., 2016) and amino acid levels(Watne et al., 2016), and a low A $\beta /$ tau ratio(Xie et al., 2014) conferred an increased risk of delirium. Collection during delirium was associated with reduced BLI(Koponen and Riekkinen, 1990) and SLI(Koponen et al., 1994b), increased IL-1ra(Cape et al., 2014), neopterin(Hall et al., 2016), lactate, protein(Caplan et al., 2010), $\alpha 1$-glycoprotein(Poljak et al., 2014) and S100B(Beishuizen et al., 2015), lower NSE(Caplan et al., 2010) and in those without prior cognitive impairment, higher CRP(Neerland et al., 2016) and 5-HIAA(Watne et al., 2016). 


\section{Methodological issues}

Several of the studies could have been influenced by bias or confounding. Sample sizes were generally small. More recent collaborative studies collecting CSF at the onset of spinal anaesthetic have been larger, with lower risk of bias, but several included the same participants as in previous published articles. A diverse range of populations was studied, and generally patients with delirium were frailer, older, and more often had dementia. There is likely to be a high proportion of unrecognised dementia in the cohorts of patients with hip fracture and elderly medical inpatients. A further potential confounding factor in these heterogeneous groups of patients is the underlying precipitants of delirium.

Serum values were reported in eleven studies. Interestingly, the direction of change in markers measured in both CSF and serum was sometimes at odds, illustrating the limitations in using analyses in blood to measure biochemical changes in the brain. The timing of sampling may be crucial; there may be different pathophysiological processes occurring in a patient who is not yet delirious, compared to new active delirium or prolonged delirium. Some authors have attempted to separate these groups, whereas in some studies all these phases are included as cases. Given that levels of biomarkers may be fleeting, and may change during different phases of the delirium syndrome, longitudinal sampling of CSF might shed more light on the complex relationship between biomarkers and delirium.

In addition to timing, other pre-analytical variables may affect the results, with differences in the handling of CSF samples possibly contributing to the heterogeneity of results. Several potential variables of interest highlighted by work in the AD biomarker field are outlined in 
Table 4. Analysis methods are outlined in Table 1. Whilst proteomic technologies and automated assays are increasingly frequently employed, enzyme-linked immunosorbent assay (ELISA)-based technologies remain the cornerstone of many delirium studies and analytical factors are also therefore still very relevant. All authors specified the kits used as a minimum. Several authors specified that analyses were undertaken by a single researcher at the same time point (thus decreasing laboratory practice variability). Analysis of samples in duplicate or triplicate is inconsistently reported, as are coefficients of variation (CV). Analytical variation is often high at low concentrations close to the analytical sensitivity of the assay and results may therefore be uncertain for some low abundant cytokines.

This review was limited to studies published in English or Norwegian. Despite our extensive search, we might have missed eligible articles. As the authors of this review have been involved in several of the recent published articles, it might make us less objective on the faults of those articles. A strength is that we have insisted on formal delirium diagnosis by DSM or ICD criteria, or a method based upon this.

\section{Challenges and implications for future research}

CSF research in delirium faces several significant challenges. Care must be taken with potential participants who may lack capacity to consent to participation in such studies (Holt et al., 2008), and in particular when an invasive investigation such as CSF examination is proposed. Since 2010, many studies have taken the approach of collecting CSF opportunistically from patients undergoing spinal anaesthetic for surgery. Hip fracture patients are the most studied group. With delirium and dementia being prevalent in this population, we believe this will continue to be an important model for CSF delirium research in the future. An important limitation with all studies recruiting acutely admitted patients is 
however the lack of opportunity to do objective cognitive testing before admission. Where there is potential concomitant dementia, it is very difficult to determine whether observed changes are related to acute delirium or confounded by underlying dementia pathology (Inouye and Ferrucci, 2006). Studies including elective patients can readily involve preoperative cognitive testing, but the prevalence of delirium is much lower. Also, no patients will have ongoing delirium in studies of elective patients so CSF analyses are limited to giving information regarding risk factors for delirium.

It is important to avoid being too restrictive in performing LP for research purposes in delirium. LP is safe with post-LP headache being the only significant side-effect (less common in the elderly) (Duits et al., 2016). Additionally, LP is sometimes carried out in the investigation of delirium, when certain primary brain disorders are suspected. Therefore, with sufficient care and selection of patients, we believe that studies of the CSF in delirium need not be restricted to opportunistic use of clinical samples or only where spinal anaesthesia is being performed.

Future studies need to be informed by prior research, clearly report baseline characteristics of all subjects, and ensure blinding wherever possible. In order to carry out subgroup analyses, which are clearly necessary, larger patient cohorts are needed with standardised and detailed methods of recording of predisposing and precipitating factors. Standardised, detailed assessment of delirium presence as well its severity is essential, including (where possible) ascertainment of the presence or absence of psychotic features, the motoric subtypes, and the presumed aetiologies including where drug toxicity is a likely major factor. This will allow additional exploration of pathophysiological subtypes. Standardisation of the collection and handling of CSF will facilitate exchange of samples between centres. Ideally more generalisable populations of medical and surgical patients should be studied. Information about prior cognitive status is important, and should always be collected in studies recruiting 
acutely admitted patients, through documentation of known prior dementia, and use of an informant questionnaire. Details regarding our recommendations for future studies are given in Table 4.

[insert Table 4 around here]

\section{Conclusion}

In recent years there has been a blossoming of studies examining CSF in delirium. The heterogeneity of the studies preclude firm conclusions regarding the pathophysiology of delirium.Nevertheless, the overall interpretation of the literature supports the vulnerable brain concept, that is that biomarker evidence of, for example AD pathology and/or neuroinflammation is associated with delirium. A concerted effort is now required to standardise several aspects of the methodology and reporting of these studies, in order to advance this highly promising avenue of delirium research.

\section{Conflict of interest}

None declared.

\section{Acknowledgement}

LOW is funded by The Norwegian Association for Public Health 
Reference List

AHMED, S., LEURENT, B. \& SAMPSON, E. L. 2014. Risk factors for incident delirium among older people in acute hospital medical units: a systematic review and meta-analysis. Age Ageing, 43, 326-33.

ALLAN, S. M., TYRRELL, P. J. \& ROTHWELL, N. J. 2005. Interleukin-1 and neuronal injury. Nat Rev Immunol, 5, 629-40.

BEISHUIZEN, S. J., SCHOLTENS, R. M., VELLEKOOP, A. E., VROUENRAETS, B. C., WESTHOFF, D., VAN DE BEEK, D., DE ROOIJ, S. E. \& VAN MUNSTER, B. C. 2015. Timing Is Critical in Determining the Association Between Delirium and S100 Calcium-Binding Protein B. J Am Geriatr Soc, 63, 2212-4.

BLENNOW, K., HAMPEL, H., WEINER, M. \& ZETTERBERG, H. 2010. Cerebrospinal fluid and plasma biomarkers in Alzheimer disease. Nat Rev Neurol, 6, 131-44.

CAPE, E., HALL, R. J., VAN MUNSTER, B. C., DE VRIES, A., HOWIE, S. E., PEARSON, A., MIDDLETON, S. D., GILLIES, F., ARMSTRONG, I. R., WHITE, T. O., CUNNINGHAM, C., DE ROOIJ, S. E. \& MACLULLICH, A. M. 2014. Cerebrospinal fluid markers of neuroinflammation in delirium: A role for interleukin-1beta in delirium after hip fracture. J Psychosom Res. 77, 219-25.

CAPLAN, G. A., KVELDE, T., LAI, C., YAP, S. L., LIN, C. \& HILL, M. A. 2010. Cerebrospinal Fluid in LongLasting Delirium Compared With Alzheimer's Dementia. The Journals of Gerontology Series A: Biological Sciences and Medical Sciences, 65A, 1130-1136.

CEREJEIRA, J., FIRMINO, H. Í., VAZ-SERRA, A. \& MUKAETOVA-LADINSKA, E. 2010. The neuroinflammatory hypothesis of delirium. Acta Neuropathologica, 119, 737-754.

CUNNINGHAM, C. \& MACLULLICH, A. M. 2013. At the extreme end of the psychoneuroimmunological spectrum: delirium as a maladaptive sickness behaviour response. Brain Behav Immun, 28, 113.

CUNNINGHAM, C., WILCOCKSON, D. C., BOCHE, D. \& PERRY, V. H. 2005. Comparison of inflammatory and acute-phase responses in the brain and peripheral organs of the ME7 model of prion disease. J Virol, 79, 5174-84.

DAVIS, D. H., MUNIZ-TERRERA, G., KEAGE, H. A., STEPHAN, B. C., FLEMING, J., INCE, P. G., MATTHEWS, F. E., CUNNINGHAM, C., ELY, E. W., MACLULLICH, A. M. \& BRAYNE, C. 2017. Association of Delirium With Cognitive Decline in Late Life: A Neuropathologic Study of 3 Population-Based Cohort Studies. JAMA Psychiatry, 74, 244-251.

DAVIS, D. H. J., TERRERA, G. M., KEAGE, H., RAHKONEN, T., OINAS, M., MATTHEWS, F. E., CUNNINGHAM, C., POLVIKOSKI, T., SULKAVA, R., MACLULLICH, A. M. J. \& BRAYNE, C. 2012. Delirium is a strong risk factor for dementia in the oldest-old: a population-based cohort study. Brain, 135, 2809-2816.

DUITS, F. H., MARTINEZ-LAGE, P., PAQUET, C., ENGELBORGHS, S., LLEO, A., HAUSNER, L., MOLINUEVO, J. L., STOMRUD, E., FAROTTI, L., RAMAKERS, I. H., TSOLAKI, M., SKARSGARD, C., ASTRAND, R., WALLIN, A., VYHNALEK, M., HOLMBER-CLAUSEN, M., FORLENZA, O. V., GHEZZI, L., INGELSSON, M., HOFF, E. I., ROKS, G., DE MENDONCA, A., PAPMA, J. M., IZAGIRRE, A., TAGA, M., STRUYFS, H., ALCOLEA, D. A., FROLICH, L., BALASA, M., MINTHON, L., TWISK, J. W., PERSSON, S., ZETTERBERG, H., VAN DER FLIER, W. M., TEUNISSEN, C. E., SCHELTENS, P. \& BLENNOW, K. 2016. Performance and complications of lumbar puncture in memory clinics: Results of the multicenter lumbar puncture feasibility study. Alzheimers Dement, 12, 154-63.

FONG, T. G., DAVIS, D., GROWDON, M. E., ALBUQUERQUE, A. \& INOUYE, S. K. 2015. The interface between delirium and dementia in elderly adults. Lancet Neurol, 14, 823-32.

GODBOUT, J. P. \& JOHNSON, R. W. 2006. Age and neuroinflammation: a lifetime of psychoneuroimmune consequences. Neurol Clin, 24, 521-38.

HALL, R. J., FERGUSON, K. J., ANDREWS, M., GREEN, A. J., WHITE, T. O., ARMSTRONG, I. R. \& MACLULLICH, A. M. 2013. Delirium and Cerebrospinal Fluid S100B in Hip Fracture Patients: A Preliminary Study. Am J Geriatr Psychiatry. 21, 1239-43. 
HALL, R. J., SHENKIN, S. D. \& MACLULLICH, A. M. J. 2011. A Systematic Literature Review of Cerebrospinal Fluid Biomarkers in Delirium. Dementia and Geriatric Cognitive Disorders, 32, 79-93.

HALL, R. J., WATNE, L. O., IDLAND, A. V., RAEDER, J., FRIHAGEN, F., MACLULLICH, A. M., STAFF, A. C., WYLLER, T. B. \& FEKKES, D. 2016. Cerebrospinal fluid levels of neopterin are elevated in delirium after hip fracture. J Neuroinflammation, 13, 170.

HIRSCH, J., VACAS, S., TERRANDO, N., YUAN, M., SANDS, L. P., KRAMER, J., BOZIC, K., MAZE, M. M. \& LEUNG, J. M. 2016. Perioperative cerebrospinal fluid and plasma inflammatory markers after orthopedic surgery. J Neuroinflammation, 13, 211.

HOLT, R., SIDDIQI, N. \& YOUNG, J. 2008. The ethics of consent in delirium studies. J Psychosom Res, 65, 283-7.

HOV, K. R., BERG, J. P., FRIHAGEN, F., RAEDER, J., HALL, R., WYLLER, T. B. \& WATNE, L. O. 2016. BloodCerebrospinal Fluid Barrier Integrity in Delirium Determined by Q-Albumin. Dement Geriatr Cogn Disord, 41, 192-8.

IDLAND, A. V., WYLLER, T. B., STOEN, R., ERI, L. M., FRIHAGEN, F., RAEDER, J., CHAUDHRY, F. A., HANSSON, O., ZETTERBERG, H., BLENNOW, K., BOGDANOVIC, N., BRAEKHUS, A. \& WATNE, L. O. 2017. Preclinical Amyloid-beta and Axonal Degeneration Pathology in Delirium. $J$ Alzheimers Dis. 55, 371-379.

INOUYE, S. K. \& FERRUCCI, L. 2006. Elucidating the pathophysiology of delirium and the interrelationship of delirium and dementia. J Gerontol A Biol Sci Med Sci, 61, 1277-80.

INOUYE, S. K., WESTENDORP, R. G. \& SACZYNSKI, J. S. 2013. Delirium in elderly people. Lancet. 383, 911-22.

JOHANSON, C. E., DUNCAN, J. A., 3RD, KLINGE, P. M., BRINKER, T., STOPA, E. G. \& SILVERBERG, G. D. 2008. Multiplicity of cerebrospinal fluid functions: New challenges in health and disease. Cerebrospinal Fluid Res, 5, 10.

KIM, S. Y., PARK, J. E., LEE, Y. J., SEO, H. J., SHEEN, S. S., HAHN, S., JANG, B. H. \& SON, H. J. 2013. Testing a tool for assessing the risk of bias for nonrandomized studies showed moderate reliability and promising validity. J Clin Epidemiol, 66, 408-14.

KOPONEN, H. \& RIEKKINEN, J. 1990. A longitudinal study of cerebrospinal fluid beta-endorphin-like immunoreactivity in delirium: changes at the acute stage and at one-year follow-up. Acta Psychiatrica Scandinavica, 82, 323-326.

KOPONEN, H., SIRVI+Â, J., LEPOLA, U., LEINONEN, E. \& RIEKKINEN, P. 1994a. A long-term follow-up study of cerebrospinal fluid acetylcholinesterase in delirium. European Archives of Psychiatry and Clinical Neuroscience, 243, 347-351.

KOPONEN, H. J., LEINONEN, E., LEPOLA, U. \& RIEKKINEN, P. J. 1994b. A long-term follow-up study of cerebrospinal fluid somatostatin in delirium. Acta Psychiatr Scand, 89, 329-34.

KOPONEN, H. J., LEPOLA, U. \& LEINONEN, E. 1994c. A long-term follow-up study of cerebrospinal fluid 5-hydroxyindoleacetic acid in delirium. Eur Arch Psychiatry Clin Neurosci, 244, 131-4.

KROGSETH, M., WATNE, L. O., JULIEBO, V., SKOVLUND, E., ENGEDAL, K., FRIHAGEN, F. \& WYLLER, T. B. 2016. Delirium is a risk factor for further cognitive decline in cognitively impaired hip fracture patients. Arch Gerontol Geriatr, 64, 38-44.

LIBERATI, A., ALTMAN, D. G., TETZLAFF, J., MULROW, C., GOTZSCHE, P. C., IOANNIDIS, J. P., CLARKE, M., DEVEREAUX, P. J., KLEIJNEN, J. \& MOHER, D. 2009. The PRISMA statement for reporting systematic reviews and meta-analyses of studies that evaluate healthcare interventions: explanation and elaboration. Bmj, 339, b2700.

LOUVEAU, A., SMIRNOV, I., KEYES, T. J., ECCLES, J. D., ROUHANI, S. J., PESKE, J. D., DERECKI, N. C., CASTLE, D., MANDELL, J. W., LEE, K. S., HARRIS, T. H. \& KIPNIS, J. 2015. Structural and functional features of central nervous system lymphatic vessels. Nature, 523, 337-41.

MACLULLICH, A. M., EDELSHAIN, B. T., HALL, R. J., DE, V. A., HOWIE, S. E., PEARSON, A., MIDDLETON, S. D., GILLIES, F., ARMSTRONG, I. R., WHITE, T. O., CUNNINGHAM, C., DE ROOIJ, S. E. \& VAN MUNSTER, B. C. 2011. Cerebrospinal fluid interleukin-8 levels are higher in people with hip fracture with perioperative delirium than in controls. J Am Geriatr Soc, 59, 1151-1153. 
MACLULLICH, A. M., FERGUSON, K. J., MILLER, T., DE ROOIJ, S. E. \& CUNNINGHAM, C. 2008. Unravelling the pathophysiology of delirium: a focus on the role of aberrant stress responses. [Review] [100 refs]. Journal of Psychosomatic Research, 65, 229-238.

MALDONADO, J. R. 2013. Neuropathogenesis of delirium: review of current etiologic theories and common pathways. Am J Geriatr Psychiatry, 21, 1190-222.

NEERLAND, B. E., HALL, R. J., SELJEFLOT, I., FRIHAGEN, F., MACLULLICH, A. M., RAEDER, J., WYLLER, T. B. \& WATNE, L. O. 2016. Associations Between Delirium and Preoperative Cerebrospinal Fluid C-Reactive Protein, Interleukin-6, and Interleukin-6 Receptor in Individuals with Acute Hip Fracture. J Am Geriatr Soc, 64, 1456-63.

OLSSON, T. 1999. Activity in the hypothalamic-pituitary-adrenal axis and delirium. Dement Geriatr Cogn Disord, 10, 345-9.

PEARSON, A., DE VRIES, A., MIDDLETON, S., GILLIES, F., WHITE, T., ARMSTRONG, I., ANDREW, R., SECKL, J. \& MACLULLICH, A. 2010. Cerebrospinal fluid cortisol levels are higher in patients with delirium versus controls. BMC Research Notes, 3, 33.

PERRY, V. H., CUNNINGHAM, C. \& HOLMES, C. 2007. Systemic infections and inflammation affect chronic neurodegeneration. Nat Rev Immunol, 7, 161-7.

POLJAK, A., HILL, M., HALL, R. J., MACLULLICH, A. M., RAFTERY, M. J., TAI, J., YAN, S. \& CAPLAN, G. A. 2014. Quantitative proteomics of delirium cerebrospinal fluid. Transl Psychiatry, 4, e477.

RAMIREZ-BERMUDEZ, J., RUIZ-CHOW, A., PEREZ-NERI, I., SOTO-HERNANDEZ, J. L., FLORESHERNANDEZ, R., NENTE, F., MONTES, S. \& RIOS, C. 2008. Cerebrospinal fluid homovanillic acid is correlated to psychotic features in neurological patients with delirium. General Hospital Psychiatry, 30, 337-343.

TATA, D. A. \& ANDERSON, B. J. 2010. The effects of chronic glucocorticoid exposure on dendritic length, synapse numbers and glial volume in animal models: implications for hippocampal volume reductions in depression. Physiol Behav, 99, 186-93.

TRZEPACZ, P. T. 2000. Is there a final common neural pathway in delirium? Focus on acetylcholine and dopamine. Semin.Clin.Neuropsychiatry, 5, 132-148.

WATNE, L. O., HALL, R. J., MOLDEN, E., RAEDER, J., FRIHAGEN, F., MACLULLICH, A. M., JULIEBO, V., NYMAN, A., MEAGHER, D. \& WYLLER, T. B. 2014. Anticholinergic Activity in Cerebrospinal Fluid and Serum in Individuals with Hip Fracture with and without Delirium. J Am Geriatr Soc. 62, 94-102.

WATNE, L. O., IDLAND, A. V., FEKKES, D., RAEDER, J., FRIHAGEN, F., RANHOFF, A. H., CHAUDHRY, F. A., ENGEDAL, K., WYLLER, T. B. \& HASSEL, B. 2016. Increased CSF levels of aromatic amino acids in hip fracture patients with delirium suggests higher monoaminergic activity. BMC Geriatr, 16, 149.

WESTHOFF, D., WITLOX, J., KOENDERMAN, L., KALISVAART, K. J., DE JONGHE, J. F., VAN STIJN, M. F., HOUDIJK, A. P., HOOGLAND, I. C., MACLULLICH, A. M., VAN WESTERLOO, D. J., VAN DE BEEK, D., EIKELENBOOM, P. \& VAN GOOL, W. A. 2013. Preoperative cerebrospinal fluid cytokine levels and the risk of postoperative delirium in elderly hip fracture patients. $J$ Neuroinflammation, 10, 122.

WESTHOFF, D., WITLOX, J., VAN AALST, C., SCHOLTENS, R. M., DE ROOIJ, S. E., VAN MUNSTER, B. C., DE JONGHE, J. F., HOUDIJK, A. P., EIKELENBOOM, P., VAN WESTERLOO, D. J., VAN DE BEEK, D., VAN GOOL, W. A. \& KOENDERMAN, L. 2015. Preoperative protein profiles in cerebrospinal fluid in elderly hip fracture patients at risk for delirium: A proteomics and validation study. BBA Clin, 4, 115-22.

WITLOX, J., EURELINGS, L. S. M., DE JONGHE, J. F. M., KALISVAART, K. J., EIKELENBOOM, P. \& VAN GOOL, W. A. 2010. Delirium in Elderly Patients and the Risk of Postdischarge Mortality, Institutionalization, and Dementia. The Journal of the American Medical Association, 304, 443-451.

WITLOX, J., KALISVAART, K. J., DE JONGHE, J. F. M., VERWEY, N. A., VAN STIJN, M. F. M., HOUDIJK, A. P. J., TRAAST, H. S., MACLULLICH, A. M. J., VAN GOOL, W. A. \& EIKELENBOOM, P. 2011. Cerebrospinal Fluid + -Amyloid and Tau Are Not Associated with Risk of Delirium: A 
Prospective Cohort Study in Older Adults with Hip Fracture. Journal of the American Geriatrics Society, 59, 1260-1267.

XIE, Z., SWAIN, C. A., WARD, S. A., ZHENG, H., DONG, Y., SUNDER, N., BURKE, D. W., ESCOBAR, D., ZHANG, Y. \& MARCANTONIO, E. R. 2014. Preoperative cerebrospinal fluid beta-Amyloid/Tau ratio and postoperative delirium. Ann Clin Transl Neurol, 1, 319-328. 
FIGURE LEGENDS

Figure 1. Study selection 


\begin{tabular}{|c|c|c|c|c|c|c|c|c|}
\hline Study / provenance & Design / setting & $\begin{array}{l}\text { Biomarker(s) studied } \\
\text { (Method used) }\end{array}$ & $\begin{array}{l}\text { Causes of } \\
\text { delirium }\end{array}$ & $\begin{array}{l}\text { Age } \\
\text { Mean or } \\
\text { median }\end{array}$ & $\begin{array}{l}\text { Sex (\% } \\
\text { male) }\end{array}$ & Cases & Controls & $\begin{array}{l}\text { Timing of CSF } \\
\text { sampling } \\
\mathrm{N} \text { delirious at } \\
\mathrm{LP}\end{array}$ \\
\hline & & & & & & 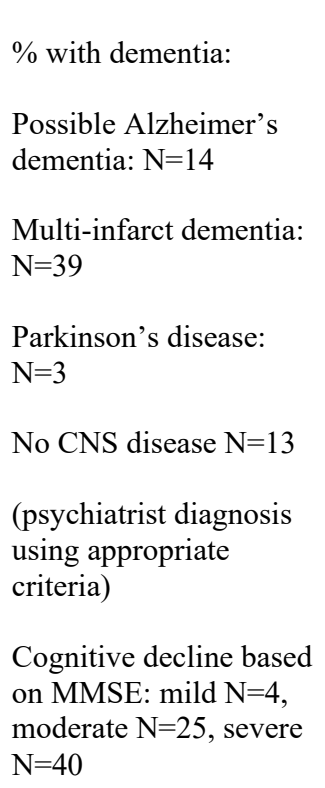 & $\%$ with dementia: $0 \%$ & $\begin{array}{l}1 \text { year: after } \\
\text { delirium } \\
0 / 33 \\
\begin{array}{l}4 \text { years: after } \\
\text { delirium } \\
0 / 11\end{array}\end{array}$ \\
\hline
\end{tabular}




\begin{tabular}{|c|c|c|c|c|c|c|c|c|}
\hline $\begin{array}{l}\text { Ramirez-Bermudez et } \\
\text { al(Ramirez-Bermudez } \\
\text { et al., 2008) } \\
\text { Mexico }\end{array}$ & $\begin{array}{l}\text { Prospective } \\
\text { cohort study } \\
\text { General } \\
\text { Hospital }\end{array}$ & HVA (HPLC) & $\begin{array}{l}\text { Primarily acute } \\
\text { CNS infection }\end{array}$ & $\begin{array}{l}\text { Whole } \\
\text { sample: } \\
36\end{array}$ & $\begin{array}{l}\text { Whole } \\
\text { sample: } \\
55\end{array}$ & $\begin{array}{l}\text { Documented dementia } \\
\text { excluded }\end{array}$ & $\begin{array}{l}\mathrm{n}=20 \\
\text { Documented dementia } \\
\text { excluded }\end{array}$ & $\begin{array}{l}\text { During delirium } \\
\text { (within 24h of } \\
\text { neuropsychologi } \\
\text { cal testing) } \\
31 / 31\end{array}$ \\
\hline $\begin{array}{l}\text { Caplan et al(Caplan et } \\
\text { al., 2010) } \\
\text { Australia }\end{array}$ & $\begin{array}{l}\text { Prospective } \\
\text { cohort study } \\
\text { General } \\
\text { Hospital }\end{array}$ & $\begin{array}{l}\text { Lactate, NSE, S100B, } \\
\text { Glucose, Protein } \\
\text { (ELISA for S100B } \\
\text { and NSE, in-house } \\
\text { laboratory for lactate, } \\
\text { protein and glucose) }\end{array}$ & $\begin{array}{l}\text { Heterogeneous, } \\
\text { acute medical } \\
\text { illness }\end{array}$ & $\begin{array}{l}\text { Cases: } 82 \\
\text { Controls: } \\
81\end{array}$ & Not stated & $\begin{array}{l}\mathrm{n}=20 \\
\text { \% with dementia: not } \\
\text { stated (mean IQCODE } \\
3.7 \text { ) }\end{array}$ & $\begin{array}{l}\mathrm{n}=20 \\
\text { \% with dementia: } 100 \\
\text { (Alzheimer's dementia) }\end{array}$ & $\begin{array}{l}\text { During delirium } \\
(>5 \text { days } \\
\text { duration }) \\
20 / 20\end{array}$ \\
\hline $\begin{array}{l}\text { Pearson et al(Pearson } \\
\text { et al., 2010) } \\
\text { Scotland }\end{array}$ & $\begin{array}{l}\text { Prospective } \\
\text { cohort study } \\
\text { General } \\
\text { Hospital }\end{array}$ & $\begin{array}{l}\text { Cortisol (RIA for } \\
\text { plasma levels, ELISA } \\
\text { for CSF levels) }\end{array}$ & $\begin{array}{l}\text { Hip fracture and } \\
\text { consequent } \\
\text { surgery }\end{array}$ & $\begin{array}{l}\text { Cases: } 81 \\
\text { Controls: } \\
81\end{array}$ & $\begin{array}{l}\text { Whole } \\
\text { sample: } \\
25\end{array}$ & $\begin{array}{l}\mathrm{n}=7 \\
\text { Documented dementia } \\
\text { excluded }\end{array}$ & $\begin{array}{l}\mathrm{n}=13 \\
\\
\begin{array}{l}\text { Documented dementia } \\
\text { excluded }\end{array}\end{array}$ & $\begin{array}{l}\text { Number } \\
\text { delirious at } \\
\text { collection not } \\
\text { stated }\end{array}$ \\
\hline $\begin{array}{l}\text { MacLullich et } \\
\text { al(MacLullich et al., } \\
\text { 2011) } \\
\text { Scotland and the } \\
\text { Netherlands }\end{array}$ & $\begin{array}{l}\text { Prospective } \\
\text { cohort study } \\
\text { General } \\
\text { Hospital }\end{array}$ & $\begin{array}{l}\text { TNF- } \alpha, \text { IL-1 } 1 \beta, \text { IL-6, } \\
\text { IL- } 8, \text { IL-10 and IL- } \\
12 p 70 \\
\text { (Cytometric bead } \\
\text { array) }\end{array}$ & $\begin{array}{l}\text { Hip fracture and } \\
\text { consequent } \\
\text { surgery }\end{array}$ & & Not stated & $\begin{array}{l}\mathrm{n}=15 \\
\text { \% with dementia: not } \\
\text { stated ( } 7 \text { in whole } \\
\text { sample) }\end{array}$ & $\begin{array}{l}\% \text { with dementia: not } \\
\text { stated ( } 7 \text { in whole } \\
\text { sample) }\end{array}$ & $\begin{array}{l}\text { Before and } \\
\text { during delirium, } \\
\text { grouped } \\
\text { together for } \\
\text { statistical } \\
\text { analysis } \\
9 / 36\end{array}$ \\
\hline $\begin{array}{l}\text { Witlox et al(Witlox et } \\
\text { al., 2011) } \\
\text { The Netherlands }\end{array}$ & $\begin{array}{l}\text { Prospective } \\
\text { cohort study } \\
\text { nested within a } \\
\text { randomised } \\
\text { controlled trial }\end{array}$ & $\begin{array}{l}\text { A } \beta 42, \text { t-tau, p-tau } \\
\text { (ELISA) }\end{array}$ & $\begin{array}{l}\text { Hip fracture and } \\
\text { consequent } \\
\text { surgery }\end{array}$ & $\begin{array}{l}\text { Cases: } 85 \\
\text { Controls: } \\
82\end{array}$ & $\begin{array}{l}\text { Cases: } 33 \\
\text { Controls: } \\
33\end{array}$ & $\mathrm{n}=30$ & $\mathrm{n}=46$ & $\begin{array}{l}\text { Before delirium } \\
0 / 76\end{array}$ \\
\hline
\end{tabular}




\begin{tabular}{|c|c|c|c|c|c|c|c|c|}
\hline & $\begin{array}{l}\text { General } \\
\text { Hospital }\end{array}$ & & & & & $\begin{array}{l}\text { \% with dementia: } 64 \\
\text { (defined as IQCODE > } \\
\text { 3.6) }\end{array}$ & $\begin{array}{l}\text { \% with dementia: } 16 \\
\text { (defined as IQCODE > } \\
\text { 3.6) }\end{array}$ & \\
\hline $\begin{array}{l}\text { Hall et al(Hall et al., } \\
\text { 2013) } \\
\text { Scotland }\end{array}$ & $\begin{array}{l}\text { Prospective } \\
\text { cohort study }\end{array}$ & S100B (ELISA) & $\begin{array}{l}\text { Hip fracture and } \\
\text { consequent } \\
\text { surgery }\end{array}$ & $\begin{array}{l}\text { Cases: } 81 \\
\text { Controls: } \\
79\end{array}$ & $\begin{array}{l}\text { Cases: } 37 \\
\text { Controls: } \\
27\end{array}$ & $\begin{array}{l}\mathrm{n}=19 \\
\text { \% with dementia: } 32 \\
\text { (defined as IQCODE > } \\
3.44 \text { ) }\end{array}$ & $\begin{array}{l}\mathrm{n}=26 \\
\% \text { with dementia: } 0 \\
\text { (defined as IQCODE > } \\
\text { 3.44) }\end{array}$ & $\begin{array}{l}\text { Before and } \\
\text { during delirium } \\
8 / 45\end{array}$ \\
\hline $\begin{array}{l}\text { Cape et al(Cape et al., } \\
\text { 2014) } \\
\text { Scotland and the } \\
\text { Netherlands }\end{array}$ & $\begin{array}{l}\text { Prospective } \\
\text { cohort study }\end{array}$ & $\begin{array}{l}\text { IL-1 } \beta, \text { IL-1ra, IGF-1, } \\
\text { GFAP, IFN- } \gamma \\
\text { (ELISA) }\end{array}$ & $\begin{array}{l}\text { Hip fracture and } \\
\text { consequent } \\
\text { surgery }\end{array}$ & $\begin{array}{l}\text { Cases: } 81 \\
\text { Controls: } \\
81\end{array}$ & $\begin{array}{l}\text { Cases: } 26 \\
\text { Controls: } \\
25\end{array}$ & $\begin{array}{l}\mathrm{n}=19 \\
\text { \% with dementia: } 41 \\
\text { (defined as IQCODE > } \\
\text { 3.44) }\end{array}$ & $\begin{array}{l}\mathrm{n}=24 \\
\\
\text { \% with dementia: } 4 \\
\text { (defined as IQCODE > } \\
3.44 \text { ) }\end{array}$ & $\begin{array}{l}\text { Before and } \\
\text { during delirium } \\
8 / 43\end{array}$ \\
\hline $\begin{array}{l}\text { Poljak et al(Poljak et } \\
\text { al., 2014) } \\
\text { Australia and Scotland }\end{array}$ & $\begin{array}{l}\text { Prospective } \\
\text { cohort study }\end{array}$ & Proteomics & $\begin{array}{l}\text { Heterogeneous, } \\
\text { acute medical } \\
\text { illness (Australia) } \\
\text { Hip fracture and } \\
\text { consequent } \\
\text { surgery (Scotland) }\end{array}$ & $\begin{array}{l}\text { Cases: } 82 \\
\text { Controls: } 8 \\
2\end{array}$ & $\begin{array}{l}\text { Cases: } 60 \\
\text { Controls: } \\
30\end{array}$ & $\begin{array}{l}\mathrm{n}=17 \\
\% \text { with dementia: not } \\
\text { stated (mean IQCODE } \\
4.0 \text { in Sydney group and } \\
3.3 \text { in Edinburgh group) }\end{array}$ & $\begin{array}{l}\mathrm{n}=8 \text { normal control } \\
\mathrm{n}=17 \text { Alzheimer's } \\
\text { dementia }\end{array}$ & $\begin{array}{l}\text { During delirium } \\
17 / 42\end{array}$ \\
\hline
\end{tabular}




\begin{tabular}{|c|c|c|c|c|c|c|c|c|}
\hline $\begin{array}{l}\text { Watne et al(Watne et } \\
\text { al., 2014) } \\
\text { Norway and Scotland }\end{array}$ & 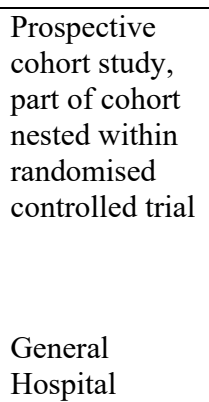 & $\begin{array}{l}\text { Anticholinergic } \\
\text { activity (muscarinic } \\
\text { radio receptor } \\
\text { bioassay) }\end{array}$ & $\begin{array}{l}\text { Hip fracture and } \\
\text { consequent } \\
\text { surgery }\end{array}$ & $\begin{array}{l}\text { Cases: } 85 \\
\text { Controls: } \\
83\end{array}$ & $\begin{array}{l}\text { Cases: } 29 \\
\text { Controls: } \\
21\end{array}$ & $\begin{array}{l}\mathrm{n}=72 \\
\% \text { with dementia: } 65 \\
\text { (defined as IQCODE > } \\
\text { 3.44) }\end{array}$ & $\begin{array}{l}\mathrm{n}=79 \\
\\
\text { \% with dementia: } 13 \\
\text { (defined as IQCODE > } \\
3.44 \text { ) }\end{array}$ & $\begin{array}{l}\begin{array}{l}\text { Before and } \\
\text { during delirium } \\
38 / 151\end{array} \\
\end{array}$ \\
\hline $\begin{array}{l}\text { Beishuizen et } \\
\text { al(Beishuizen et al., } \\
\text { 2015) } \\
\text { The Netherlands }\end{array}$ & $\begin{array}{l}\text { Prospective } \\
\text { cohort study } \\
\text { General } \\
\text { Hospital }\end{array}$ & S100B (ELISA) & $\begin{array}{l}\text { Hip fracture and } \\
\text { consequent } \\
\text { surgery }\end{array}$ & $\begin{array}{l}\text { Cases: } 86 \\
\text { Controls: } \\
83\end{array}$ & Not stated & $\begin{array}{l}\mathrm{n}=15 \\
\text { \% with dementia: } 27 \\
\text { (defined as IQCODE > } \\
3.4 \text { ) }\end{array}$ & $\begin{array}{l}\mathrm{n}=51 \\
\text { \% with dementia: } 22 \\
\text { (defined as IQCODE > } \\
3.4 \text { ) }\end{array}$ & $\begin{array}{l}\text { Before and } \\
\text { during delirium } \\
2 / 66\end{array}$ \\
\hline $\begin{array}{l}\text { Westhoff et al(Westhoff } \\
\text { et al., 2015) } \\
\text { The Netherlands }\end{array}$ & $\begin{array}{l}\text { Prospective } \\
\text { cohort study } \\
\text { General } \\
\text { Hospital }\end{array}$ & $\begin{array}{l}\text { Proteomics for the } \\
\text { derivation cohort } \\
\text { Immunoassays for the } \\
\text { validation cohort }\end{array}$ & $\begin{array}{l}\text { Hip fracture and } \\
\text { consequent } \\
\text { surgery in } \\
\text { Alkmaar } \\
\text { (derivation } \\
\text { cohort) and } \\
\text { Amsterdam } \\
\text { (validation } \\
\text { cohort) }\end{array}$ & $\begin{array}{l}\text { Derivation } \\
\text { cohort: } 83 \\
\text { Validation } \\
\text { cohort: } 88\end{array}$ & $\begin{array}{l}\text { Derivation } \\
\text { cohort: } 32 \\
\text { Validation } \\
\text { cohort: } 29\end{array}$ & $\begin{array}{l}\text { Derivation cohort n=19 } \\
\text { Validation cohort n=11 } \\
\% \text { with dementia: not } \\
\text { stated, but } 26 \% \text { in } \\
\text { whole derivation cohort } \\
\text { and } 25 \% \text { in whole } \\
\text { validation cohort }\end{array}$ & $\begin{array}{l}\text { Derivation cohort } n=34 \\
\text { Validation cohort } n=41\end{array}$ & $\begin{array}{l}\text { Before delirium } \\
0 / 105\end{array}$ \\
\hline
\end{tabular}




\begin{tabular}{|c|c|c|c|c|c|c|c|c|}
\hline & & & & & & $\begin{array}{l}\text { (defined as IQCODE }> \\
3.4 \text { ) }\end{array}$ & & \\
\hline $\begin{array}{l}\text { Hirsch et al(Hirsch et } \\
\text { al., 2016) } \\
\text { USA }\end{array}$ & $\begin{array}{l}\text { Prospective } \\
\text { cohort pilot } \\
\text { study; } \\
\text { longitudinal } \\
\text { sampling over } \\
24 \mathrm{~h} \\
\text { General } \\
\text { Hospital }\end{array}$ & $\begin{array}{l}17 \text { cytokines }+\mathrm{A} \beta 42 \\
\text { and } A \beta 40 \text { (ELISA } \\
\text { and Luminex) }\end{array}$ & $\begin{array}{l}\text { Major knee } \\
\text { surgery }\end{array}$ & $\begin{array}{l}\text { Whole } \\
\text { sample: } \\
70\end{array}$ & $\begin{array}{l}\text { Whole } \\
\text { sample: } \\
70\end{array}$ & $\begin{array}{l}\mathrm{n}=1 \text { delirium } \\
\mathrm{n}=6 \text { POCD } \\
\text { Impaired cognition } \\
\text { excluded }\end{array}$ & $\mathrm{n}=3$ & $\begin{array}{l}\text { Before delirium } \\
\text { / POCD } \\
0 / 10\end{array}$ \\
\hline $\begin{array}{l}\text { Idland et al(Idland et } \\
\text { al., 2016) } \\
\text { Norway }\end{array}$ & $\begin{array}{l}\text { Prospective } \\
\text { cohort study, } \\
\text { nested within } \\
\text { randomised } \\
\text { controlled trial }\end{array}$ & $\begin{array}{l}\text { A } \beta 42, \text { t-tau, } p \text {-tau, } \\
\text { A } \beta 42 / \text { t-tau ratio, } \\
\text { A } \beta 42 / p \text {-tau ratio } \\
\text { (INNOTEST ELISA) }\end{array}$ & $\begin{array}{l}\text { Hip fracture and } \\
\text { consequent } \\
\text { surgery }\end{array}$ & $\begin{array}{l}\text { Cases: } 86 \\
\text { Controls: } \\
84\end{array}$ & $\begin{array}{l}\text { Cases: } 30 \\
\text { Controls: } \\
22\end{array}$ & $\begin{array}{l}\mathrm{n}=70 \\
\% \text { with dementia: } 77 \\
\text { (consensus diagnosis) }\end{array}$ & $\mathrm{n}=59$ & $\begin{array}{l}\text { Before and } \\
\text { during delirium } \\
43 / 129 \\
\text { (preoperative } \\
\text { delirium status }\end{array}$ \\
\hline
\end{tabular}




\begin{tabular}{|c|c|c|c|c|c|c|c|c|}
\hline & $\begin{array}{l}\text { General } \\
\text { Hospital }\end{array}$ & & & & & & & $\begin{array}{l}\text { missing for } \\
\mathrm{N}=5)\end{array}$ \\
\hline $\begin{array}{l}\text { Neerland et } \\
\text { al(Neerland et al., } \\
\text { 2016) } \\
\text { Norway and Scotland }\end{array}$ & $\begin{array}{l}\text { Prospective } \\
\text { cohort study, } \\
\text { part of cohort } \\
\text { nested within } \\
\text { randomised } \\
\text { controlled trial } \\
\text { General } \\
\text { Hospital }\end{array}$ & $\begin{array}{l}\text { CRP, IL6, sIL6R } \\
\text { (ELISA) }\end{array}$ & $\begin{array}{l}\text { Hip fracture and } \\
\text { consequent } \\
\text { surgery }\end{array}$ & $\begin{array}{l}\text { Cases: } 85 \\
\text { Controls: } \\
83\end{array}$ & $\begin{array}{l}\text { Cases: } \\
30 \% \\
\\
\text { Controls: } \\
20\end{array}$ & $\begin{array}{l}\mathrm{n}=71 \\
\% \text { with dementia: } 65 \\
\text { (defined as IQCODE > } \\
\text { 3.44) }\end{array}$ & $\begin{array}{l}\mathrm{n}=78 \\
\text { \% with dementia: } 23 \\
\text { (defined as IQCODE > } \\
3.44 \text { ) }\end{array}$ & $\begin{array}{l}\text { Before and } \\
\text { during delirium } \\
38 / 151\end{array}$ \\
\hline $\begin{array}{l}\text { Watne et al(Watne et } \\
\text { al., 2016) } \\
\text { Norway }\end{array}$ & $\begin{array}{l}\text { Prospective } \\
\text { cohort study, } \\
\text { nested within } \\
\text { randomised } \\
\text { controlled trial } \\
\text { General } \\
\text { Hospital }\end{array}$ & $\begin{array}{l}\text { Aminoacids and } \\
\text { monoamine } \\
\text { metabolites (HPLC) }\end{array}$ & $\begin{array}{l}\text { Hip fracture and } \\
\text { consequent } \\
\text { surgery }\end{array}$ & $\begin{array}{l}\text { Cases: } 86 \\
\text { Controls: } \\
84\end{array}$ & $\begin{array}{l}\text { Cases: } 30 \\
\text { Controls: } \\
29\end{array}$ & $\begin{array}{l}\mathrm{n}=53 \\
\text { \% with dementia: } 66 \\
\text { (consensus diagnosis) }\end{array}$ & $\mathrm{n}=24$ & $\begin{array}{l}\text { Before and } \\
\text { during delirium } \\
\text { 29/77 } \\
\text { (preoperative } \\
\text { delirium status } \\
\text { missing for } \\
\mathrm{N}=3 \text { ) }\end{array}$ \\
\hline
\end{tabular}

Table 1. Baseline characteristics of included studies.

5-HIAA - 5-Hydroxyindole-acetic acid. A $\beta 40$ - Amyloid- $\beta$ 1-40. A $\beta 42$ - Amyloid- $\beta$ 1-42. AChE - Acetyl-cholinesterase. BLI - Beta Endorphin-like immunoreactivity. CNS - central nervous system. ELISA - enzyme-linked immunosorbent assay. GFAP - Glial Fibrillary Acidic Protein. HPLC - High-performance liquid chromatography. HVA - Homovanillic acid. IL - interleukin

IFN- $\gamma$ - Interferon gamma. IGF - insulin like growt factor. NSE - Neuron-specific enolase. POCD - Post operative cognitive dysfunction. P-tau - phosphorylated tau. RIA - Radioimmunoassay. sIL6R - soluble IL-6 receptor. S100B - S100 calcium-binding protein B. SLI - Somatostatin-like immunoreactivity. TNF - tumor necrosis factor. T-tau - total tau. 


\begin{tabular}{|c|c|c|c|c|c|c|}
\hline \multicolumn{7}{|c|}{ Risk markers of delirium } \\
\hline \multirow{2}{*}{$\begin{array}{l}\text { Study, } \\
\text { biomarkers } \\
\text { measured }\end{array}$} & \multicolumn{6}{|l|}{ Main findings at baseline } \\
\hline & Direction of change & $\begin{array}{l}\text { Cases } \\
\text { Mean (SD) or median (range) } \\
\text { or (IQR) }\end{array}$ & $\begin{array}{l}\text { Controls } \\
\text { Mean (SD) or median } \\
\text { (range) or (IQR) }\end{array}$ & $p$-value & $\begin{array}{l}\text { Delirium } \\
\text { severity }\end{array}$ & $\begin{array}{l}\text { Delirium } \\
\text { subtype }\end{array}$ \\
\hline $\begin{array}{l}\text { Witlox et al(Witlox } \\
\text { et al., 2011) } \\
\text { A } \beta 42, \text { t-tau, p-tau }\end{array}$ & $\begin{array}{l}\text { A } \beta 42 \text { no different } \\
\text { t-tau no different } \\
\text { p-tau no different }\end{array}$ & $\begin{array}{l}631 \mathrm{pg} / \mathrm{ml}(500-985) \\
306 \mathrm{pg} / \mathrm{ml}(231--389) \\
72 \mathrm{pg} / \mathrm{ml}(51-81)\end{array}$ & $\begin{array}{l}755 \mathrm{pg} / \mathrm{ml}(567-1031) \\
325 \mathrm{pg} / \mathrm{ml}(246-523) \\
70 \mathrm{pg} / \mathrm{ml}(59-96)\end{array}$ & $\begin{array}{l}0.21 \\
0.75 \\
0.55\end{array}$ & $\begin{array}{l}\text { Not } \\
\text { measured }\end{array}$ & $\begin{array}{l}\text { Not } \\
\text { measured }\end{array}$ \\
\hline $\begin{array}{l}\text { Idland et al(Idland } \\
\text { et al., 2016) } \\
\text { A } \beta 42, \text { t-tau, p-tau }\end{array}$ & $\begin{array}{l}\downarrow \text { A } \beta 42 \text { in delirium in subgroup without prefracture dementia } \\
\uparrow \text { t-tau in delirium in subgroup without prefracture dementia } \\
\text { No difference in biomarker findings between groups with } \\
\text { prevalent, incident and never delirium }\end{array}$ & $\begin{array}{l}310 \mathrm{ng} / 1(125-633) \\
505 \mathrm{ng} / 1(187-1266)\end{array}$ & $\begin{array}{l}489 \mathrm{ng} / 1(133-1086) \\
351 \mathrm{ng} / 1(133-808)\end{array}$ & $\begin{array}{l}0.006 \\
0.02\end{array}$ & $\begin{array}{l}\text { Not } \\
\text { measured }\end{array}$ & $\begin{array}{l}\text { Not } \\
\text { measured }\end{array}$ \\
\hline
\end{tabular}




\begin{tabular}{|c|c|c|c|c|c|c|}
\hline \multicolumn{7}{|c|}{ Disease markers of delirium } \\
\hline \multirow{2}{*}{$\begin{array}{l}\text { Study, } \\
\text { biomarkers } \\
\text { measured }\end{array}$} & \multicolumn{6}{|l|}{ Main findings at baseline } \\
\hline & Direction of change & $\begin{array}{l}\text { Cases } \\
\text { Mean (SD) or median (range) } \\
\text { or (IQR) }\end{array}$ & $\begin{array}{l}\text { Controls } \\
\text { Mean (SD) or median } \\
\text { (range) or (IQR) }\end{array}$ & p-value & $\begin{array}{l}\text { Delirium } \\
\text { severity }\end{array}$ & $\begin{array}{l}\text { Delirium } \\
\text { subtype }\end{array}$ \\
\hline $\begin{array}{l}\text { Koponen et } \\
\text { al(Koponen and } \\
\text { Riekkinen, 1990) } \\
\text { BLI }\end{array}$ & $\begin{array}{l}\downarrow \text { BLI in whole delirious group } \\
\downarrow \text { BLI in delirious group with no CNS disease }\end{array}$ & $\begin{array}{l}12.5 \mathrm{pg} / \mathrm{ml}(3.0) \\
12.4 \mathrm{pg} / \mathrm{ml}(3.8)\end{array}$ & $\begin{array}{l}15.2 \mathrm{pg} / \mathrm{ml}(2.8) \\
15.2 \mathrm{pg} / \mathrm{ml}(2.8)\end{array}$ & $\begin{array}{l}<0.001 \\
<0.05\end{array}$ & $\begin{array}{l}\text { Severity of } \\
\text { cognitive } \\
\text { decline only } \\
\text { (MMSE) }\end{array}$ & $\begin{array}{l}\text { No } \\
\text { difference } \\
\text { between } \\
\text { hypoactive, } \\
\text { hyperactive } \\
\text { or mixed }\end{array}$ \\
\hline $\begin{array}{l}\text { Koponen et } \\
\text { al(Koponen et al., } \\
\text { 1994b) } \\
\text { SLI }\end{array}$ & $\begin{array}{l}\downarrow \text { SLI in whole delirious group } \\
\downarrow \text { SLI in delirious group with no central nervous system } \\
\text { (CNS) disease }\end{array}$ & $\begin{array}{l}26.2 \mathrm{pg} / \mathrm{ml}(8.8) \\
25.9 \mathrm{pg} / \mathrm{ml}(6.4)\end{array}$ & $\begin{array}{l}37.6 \mathrm{pg} / \mathrm{ml}(9.8) \\
37.6 \mathrm{pg} / \mathrm{ml}(9.8)\end{array}$ & $\begin{array}{l}<0.001 \\
<0.001\end{array}$ & $\begin{array}{l}\text { Severity of } \\
\text { cognitive } \\
\text { decline only } \\
\text { (MMSE) }\end{array}$ & $\begin{array}{l}\text { No } \\
\text { difference } \\
\text { between } \\
\text { hypoactive, } \\
\text { hyperactive } \\
\text { or mixed }\end{array}$ \\
\hline $\begin{array}{l}\text { Watne et al(Watne } \\
\text { et al., 2016) } \\
\text { Amino acids and } \\
\text { monoamine } \\
\text { metabolites }\end{array}$ & $\begin{array}{l}\uparrow \text { Aminoacid precursors of monoamines in delirium } \\
\text { Tryptophan (in those without dementia) } \\
\text { Tyrosine (in those without dementia) } \\
\text { Phenylalanine (in those without dementia) } \\
\uparrow 5 \text { HIAA in delirium in subgroup without dementia } \\
\text { Amino acid levels tended to be highest in incident delirium }\end{array}$ & $\begin{array}{l}1.1 \mu \mathrm{mol} / \mathrm{l}(0.7-1.5) \\
8 \mu \mathrm{mol} / 1(5-11) \\
14 \mu \mathrm{mol} / 1(9-19) \\
170 \mathrm{nmol} / \mathrm{l}(119-261)\end{array}$ & $\begin{array}{l}0.8 \mu \mathrm{mol} / 1(0.6-1.0) \\
5 \mu \mathrm{mol} / 1(4-7) \\
9 \mu \mathrm{mol} / 1(7-13) \\
138 \mathrm{nmol} / 1(111-156)\end{array}$ & $\begin{array}{l}0.042 \\
0.028 \\
0.014 \\
0.048\end{array}$ & $\begin{array}{l}\text { Not } \\
\text { measured }\end{array}$ & $\begin{array}{l}\text { Not } \\
\text { measured }\end{array}$ \\
\hline
\end{tabular}




\begin{tabular}{|c|c|c|c|c|c|c|}
\hline $\begin{array}{l}\text { Ramirez-Bermudez } \\
\text { et al(Ramirez- } \\
\text { Bermudez et al., } \\
\text { 2008) } \\
\text { HVA }\end{array}$ & $\begin{array}{l}\text { HVA not significantly different in delirium vs non-delirium } \\
\text { HVA } \uparrow \text { in those with hallucinations } \\
\text { HVA correlates with DRS score }(r=0.334, p=0.017)\end{array}$ & $\begin{array}{l}\text { 300.8nM (36-1915.7) } \\
\text { 436.54nM (36-1915.7) }\end{array}$ & $\begin{array}{l}231.65 \mathrm{nM}(36-1062.3) \\
192.39 \mathrm{nM}(36-1062.3)\end{array}$ & $\begin{array}{l}0.108 \\
0.018\end{array}$ & DRS & $\begin{array}{l}\text { Trend to } \\
\text { higher HVA } \\
\text { in agitated } \\
\text { subtype }\end{array}$ \\
\hline $\begin{array}{l}\text { Koponen et } \\
\text { al(Koponen et al., } \\
\text { 1994a) } \\
\text { AChE }\end{array}$ & $\begin{array}{l}\uparrow \mathrm{AChE} \text { in delirious patients who died during follow-up vs. } \\
\text { rest of cohort }\end{array}$ & $22.0 \mathrm{nmol} / \mathrm{ml} / \mathrm{min}(8.0)$ & $18.1 \mathrm{nmol} / \mathrm{ml} / \mathrm{min}(5.0)$ & 0.005 & $\begin{array}{l}\text { Severity of } \\
\text { cognitive } \\
\text { decline only } \\
\text { (MMSE) }\end{array}$ & $\begin{array}{l}\text { No } \\
\text { difference } \\
\text { between } \\
\text { hypoactive, } \\
\text { hyperactive } \\
\text { or mixedNot }\end{array}$ \\
\hline $\begin{array}{l}\text { Watne et al(Watne } \\
\text { et al., 2014) } \\
\text { Anticholinergic } \\
\text { activity }\end{array}$ & $\begin{array}{l}\text { Anticholinergic activity no different in Oslo cohort } \\
\text { Anticholinergic activity no different in Edinburgh cohort } \\
\text { No difference in AA levels between prevalent, incident, } \\
\text { subsyndromal or never delirium } \\
\text { Trend to higher CSF AA in more severe delirium in } \\
\text { Edinburgh cohort } \\
\text { CSF AA positively correlated with MDAS score in pooled } \\
\text { cohort without prefracture cognitive impairment (Spearman } \\
\text { rho=0.59, p=0.002) }\end{array}$ & $\begin{array}{l}0.39 \mathrm{pmol} / \mathrm{mL}(0.11-0.82) \\
0.36 \mathrm{pmol} / \mathrm{mL}(0.18-0.67)\end{array}$ & $\begin{array}{l}0.48 \mathrm{pmol} / \mathrm{mL}(0.24-0.98) \\
0.31 \mathrm{pmol} / \mathrm{mL}(0.10-0.75)\end{array}$ & $\begin{array}{l}0.26 \\
0.93\end{array}$ & $\begin{array}{l}\text { Oslo: } \\
\text { MDAS } \\
\text { Edinburgh: } \\
\text { DRS-R98, } \\
\text { MDAS } \\
\text { rated } \\
\text { retrospectiv } \\
\text { ely }\end{array}$ & $\begin{array}{l}\text { Not } \\
\text { measured }\end{array}$ \\
\hline $\begin{array}{l}\text { Pearson et } \\
\text { al(Pearson et al., } \\
\text { 2010) } \\
\text { Cortisol }\end{array}$ & $\uparrow$ CSF cortisol in delirium vs controls & 63.9nmol/L (40.4-102.1) & $31.4 \mathrm{nmol} / \mathrm{L}(21.7-43.3)$ & 0.029 & $\begin{array}{l}\text { MDAS used } \\
\text { but no } \\
\text { comment on } \\
\text { relationship }\end{array}$ & $\begin{array}{l}\text { Not } \\
\text { measured }\end{array}$ \\
\hline $\begin{array}{l}\text { MacLullich et } \\
\text { al(MacLullich et } \\
\text { al., 2011) } \\
\text { TNF- } \alpha, \text { IL-1 } \beta \text {, IL-6, } \\
\text { IL-8, IL-10, IL- } \\
12 \text { p70 }\end{array}$ & $\begin{array}{l}\uparrow \text { IL-8 in delirium vs. controls } \\
\text { TNF- } \alpha \text {, IL-1 } \beta, \text { IL-10 and IL-12p70 not detected }\end{array}$ & $69.8 \mathrm{pg} / \mathrm{ml}(47.9-125.6)$ & $39.6 \mathrm{pg} / \mathrm{ml}(28.0-64.6)$ & 0.003 & $\begin{array}{l}\text { Not } \\
\text { measured }\end{array}$ & $\begin{array}{l}\text { Not } \\
\text { measured }\end{array}$ \\
\hline
\end{tabular}




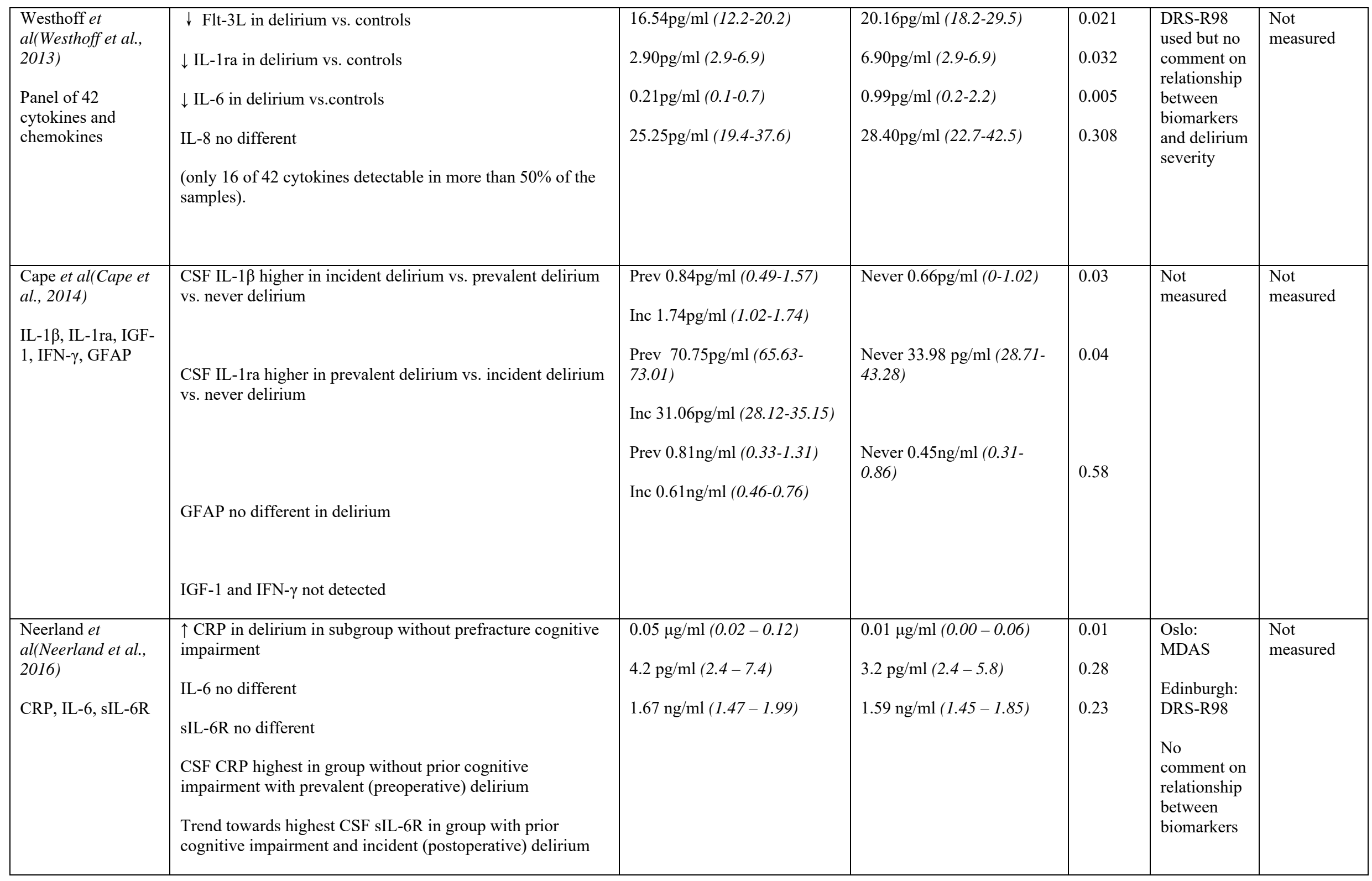




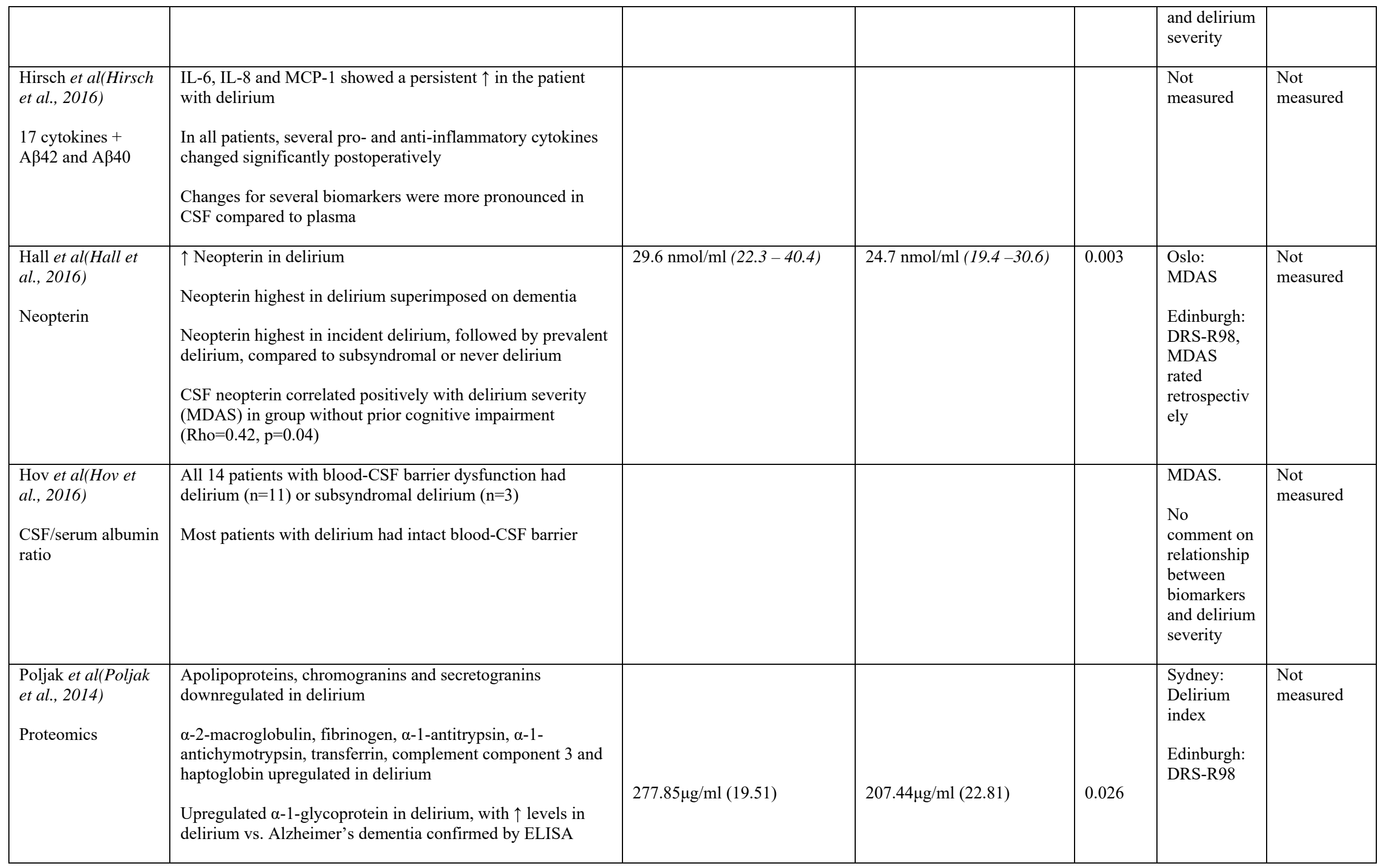




\begin{tabular}{|c|c|c|c|c|c|c|}
\hline & $\begin{array}{l}\text { Regression analysis did not find any significant association } \\
\text { between proteins identified and delirium severity }\end{array}$ & & & & & \\
\hline $\begin{array}{l}\text { Westhoff et } \\
\text { al(Westhoff et al., } \\
\text { 2015) } \\
\text { Proteomics }\end{array}$ & $\begin{array}{l}\text { Proteomics revealed } 8 \text { proteins significantly different } \\
\text { between delirium and no delirium in the derivation cohort } \\
\text { None of the findings were confirmed with immunoassay in } \\
\text { the validation cohort }\end{array}$ & & & & $\begin{array}{l}\text { Derivation } \\
\text { study: not } \\
\text { measured } \\
\text { Validation } \\
\text { cohort: } \\
\text { DOSS but } \\
\text { no comment } \\
\text { on } \\
\text { relationship }\end{array}$ & $\begin{array}{l}\text { Not } \\
\text { measured }\end{array}$ \\
\hline \multicolumn{7}{|c|}{ End-products of delirium } \\
\hline \multirow{2}{*}{$\begin{array}{l}\text { Study, } \\
\text { biomarkers } \\
\text { measured }\end{array}$} & \multicolumn{6}{|l|}{ Main findings at baseline } \\
\hline & Direction of change & $\begin{array}{l}\text { Cases } \\
\text { Mean (SD) or median (range) } \\
\text { or (IQR) }\end{array}$ & $\begin{array}{l}\text { Controls } \\
\text { Mean (SD) or median } \\
\text { (range) or (IQR) }\end{array}$ & p-value & $\begin{array}{l}\text { Delirium } \\
\text { severity }\end{array}$ & $\begin{array}{l}\text { Delirium } \\
\text { subtype }\end{array}$ \\
\hline $\begin{array}{l}\text { Caplan et } \\
\text { al(Caplan et al., } \\
\text { 2010) } \\
\text { Lactate, NSE, } \\
\text { S100B, Glucose, } \\
\text { Protein }\end{array}$ & $\begin{array}{l}\text { In delirium vs. controls with Alzheimer’s dementia: } \\
\uparrow \text { CSF lactate } \\
\downarrow \text { CSF NSE } \\
\uparrow \text { CSF protein } \\
\text { S100B no different } \\
\text { CSF lactate positively correlated with DI }(r=0.703, p<0.001) \\
\text { CSF NSE positively correlated with DI }(r=-0.467, p=0.014)\end{array}$ & $\begin{array}{l}1.87 \mathrm{mmol} / \mathrm{L}(0.31) \\
4.84 \mathrm{ng} / \mathrm{ml}(2.02) \\
0.62 \mathrm{~g} / \mathrm{L}(0.33) \\
604.8 \mathrm{pg} / \mathrm{ml}(163.0)\end{array}$ & $\begin{array}{l}1.48 \mathrm{mmol} / \mathrm{L}(0.23) \\
8.98 \mathrm{ng} / \mathrm{ml}(2.98) \\
0.44 \mathrm{~g} / \mathrm{L}(0.15) \\
697.4 \mathrm{pg} / \mathrm{ml}(306.9)\end{array}$ & $\begin{array}{l}<0.001 \\
<0.001 \\
0.036 \\
0.33\end{array}$ & $\begin{array}{l}\text { Delirium } \\
\text { index }\end{array}$ & $\begin{array}{l}\text { Comment } \\
\text { that most } \\
\text { patients had } \\
\text { mixed } \\
\text { subtype }\end{array}$ \\
\hline $\begin{array}{l}\text { Hall et al(Hall et } \\
\text { al., 2013) } \\
\text { S100B }\end{array}$ & $\uparrow \operatorname{LogS} 100 \mathrm{~B}$ in preoperative delirium & $-0.156(0.238)$ & $-0.306(0.162)$ & 0.035 & $\begin{array}{l}\text { DRS-R98 } \\
\text { measured } \\
\text { but no } \\
\text { comment on } \\
\text { relationship }\end{array}$ & $\begin{array}{l}\text { Not } \\
\text { measured }\end{array}$ \\
\hline
\end{tabular}




\begin{tabular}{|c|c|c|c|c|c|c|}
\hline $\begin{array}{l}\text { Beishuizen et } \\
\text { al(Beishuizen et al., } \\
\text { 2015) } \\
\text { S100B }\end{array}$ & $\begin{array}{l}\text { No difference in S100B } \\
\text { High S100B levels in the two patients with preoperative } \\
\text { delirium }\end{array}$ & $1053 \mathrm{pg} / \mathrm{ml}(601-1178)$ & $862 \mathrm{pg} / \mathrm{ml}(701-1177)$ & 0.76 & $\begin{array}{l}\text { Not } \\
\text { measured }\end{array}$ & $\begin{array}{l}\text { Not } \\
\text { measured }\end{array}$ \\
\hline
\end{tabular}

Table 2. Main findings of included studies.

5-HIAA - 5-Hydroxyindole-acetic acid. A $\beta 40$ - Amyloid- $\beta$ 1-40. A $\beta 42$ - Amyloid- $\beta$ 1-42. AChE - Acetyl-cholinesterase. BLI - Beta Endorphin-like immunoreactivity. DI - Delirium Index.

DOSS - Delirium Observation Screening Scale. DRS - Delirium Rating Scale. DRS-R98 - Delirium Rating Scale Revised-98. GFAP - Glial Fibrillary Acidic Protein. HVA - Homovanillic acid.

IL - interleukin. IFN- $\gamma$ - Interferon gamma. IGF - insulin like growth factor. MCP - monocyte chemotactic protein. MDAS - Memorial Delirium Assessment Scale. MMSE - Mini-Mental State Examination. NSE - Neuron-specific enolase. P-tau - phosphorylated tau. S100B - S100 calcium-binding protein B. sIL-6R - soluble IL-6 receptor. SLI - Somatostatin-like immunoreactivity.

TNF - tumor necrosis factor. T-tau - total tau. 


\begin{tabular}{|c|c|c|c|c|c|c|c|c|}
\hline \multirow[t]{2}{*}{ Study } & \multicolumn{6}{|c|}{ Assessment of risk of bias } & \multicolumn{2}{|c|}{ Additional quality points } \\
\hline & $\begin{array}{l}\text { Selection of } \\
\text { participants }\end{array}$ & $\begin{array}{l}\text { Confounding } \\
\text { variables } \\
\text { (dementia) }\end{array}$ & $\begin{array}{l}\text { Measurement of } \\
\text { exposure } \\
\text { (delirium) }\end{array}$ & $\begin{array}{l}\text { Blinding of } \\
\text { outcome } \\
\text { assessments }\end{array}$ & $\begin{array}{l}\text { Incomplete } \\
\text { outcome data }\end{array}$ & $\begin{array}{l}\text { Selective } \\
\text { outcome } \\
\text { reporting }\end{array}$ & $\begin{array}{l}\text { Power } \\
\text { calcul- } \\
\text { ation }\end{array}$ & Comments \\
\hline $\begin{array}{l}\text { Koponen(Koponen } \\
\text { et al., 1994c, } \\
\text { Koponen et al., } \\
\text { 1994b, Koponen et } \\
\text { al., 1994a, } \\
\text { Koponen and } \\
\text { Riekkinen, 1990) } \\
\text { BLI, SLI, 5-HIAA, } \\
\text { AChE }\end{array}$ & $\begin{array}{l}\text { Low } \\
\text { Consecutive }\end{array}$ & $\begin{array}{l}\text { Low } \\
\text { DSM III diagnosis } \\
\text { and subtyping }\end{array}$ & $\begin{array}{l}\text { Low } \\
\text { DSM III diagnosis }\end{array}$ & High & Low & Low & No & $\begin{array}{l}\text { Serum collected but not } \\
\text { reported }\end{array}$ \\
\hline $\begin{array}{l}\text { Ramirez- } \\
\text { Bermudez(Ramirez } \\
\text {-Bermudez et al., } \\
\text { 2008) } \\
\text { HVA }\end{array}$ & $\begin{array}{l}\text { Low } \\
\text { Consecutive }\end{array}$ & $\begin{array}{l}\text { High } \\
\text { Young cohort, } \\
\text { none with known } \\
\text { diagnosis but no } \\
\text { additional testing }\end{array}$ & $\begin{array}{l}\text { Low } \\
\text { DSM IV } \\
\text { diagnosis, DRS }\end{array}$ & Low & Low & Low & No & $\begin{array}{l}\text { Conference abstract suggests } \\
\text { other biomarkers measured } \\
\text { No paired serum }\end{array}$ \\
\hline $\begin{array}{l}\text { Caplan(Caplan et } \\
\text { al., 2010) } \\
\text { S100B, NSE, } \\
\text { protein, lactate }\end{array}$ & $\begin{array}{l}\text { High } \\
\text { Enrolment offered } \\
\text { on investigation } \\
\text { for prolonged } \\
\text { delirium on } \\
\text { clinical grounds }\end{array}$ & $\begin{array}{l}\text { Low } \\
\text { IQCODE. }\end{array}$ & $\begin{array}{l}\text { Low } \\
\text { CAM, Delirium } \\
\text { Index }\end{array}$ & High & Low & Low & No & $\begin{array}{l}\text { IQCODE comparable between } \\
\text { groups, not used to stratify } \\
\text { patients or adjust analyses } \\
\text { Delirium: controls were stable } \\
\text { AD out-patients with "no } \\
\text { evidence of delirium", no } \\
\text { formal testing } \\
\text { Paired serum }\end{array}$ \\
\hline $\begin{array}{l}\text { Pearson(Pearson et } \\
\text { al., 2010) } \\
\text { Cortisol }\end{array}$ & $\begin{array}{l}\text { High } \\
\text { Opportunistic }\end{array}$ & $\begin{array}{l}\text { High } \\
\text { Documented } \\
\text { dementia } \\
\text { excluded, no } \\
\end{array}$ & $\begin{array}{l}\text { High } \\
\text { CAM, MDAS, DSI }\end{array}$ & High & Low & Low & No & Paired serum \\
\hline
\end{tabular}




\begin{tabular}{|c|c|c|c|c|c|c|c|c|}
\hline & & $\begin{array}{l}\text { informant history } \\
\text { or IQCODE }\end{array}$ & & & & & & \\
\hline $\begin{array}{l}\text { MacLullich(MacLu } \\
\text { 1lich et al., 2011) } \\
\text { IL-8 }\end{array}$ & $\begin{array}{l}\text { High } \\
\text { Opportunistic }\end{array}$ & $\begin{array}{l}\text { High } \\
\text { Documented } \\
\text { dementia } \\
\text { excluded, no } \\
\text { informant history } \\
\text { or IQCODE }\end{array}$ & $\begin{array}{l}\text { Low } \\
\text { CAM }\end{array}$ & High & Low & Low & No & Paired serum \\
\hline $\begin{array}{l}\text { Witlox(Witlox et } \\
\text { al., 2011) } \\
\beta \text {-amyloid, tau }\end{array}$ & $\begin{array}{l}\text { Low } \\
\text { Consecutive }\end{array}$ & $\begin{array}{l}\text { Low } \\
\text { IQCODE-N, } \\
\text { MMSE }\end{array}$ & $\begin{array}{l}\text { Low } \\
\text { CAM }\end{array}$ & High & Low & Low & No & $\begin{array}{l}\text { Patients part of negative clinical } \\
\text { trial } \\
\text { Patients with known dementia } \\
\text { excluded } \\
\text { No paired serum }\end{array}$ \\
\hline $\begin{array}{l}\text { Hall(Hall et al., } \\
\text { 2013) } \\
\text { S100B }\end{array}$ & $\begin{array}{l}\text { High } \\
\text { Opportunistic }\end{array}$ & $\begin{array}{l}\text { Low } \\
\text { IQCODE }\end{array}$ & $\begin{array}{l}\text { Low } \\
\text { CAM, DRS-R98 }\end{array}$ & High & Low & Low & No & $\begin{array}{l}\text { Lab researchers blinded to } \\
\text { clinical data but not detailed in } \\
\text { paper } \\
\text { No paired serum }\end{array}$ \\
\hline $\begin{array}{l}\text { Westhoff(Westhoff } \\
\text { et al., 2013) } \\
\text { Cytokines }\end{array}$ & $\begin{array}{l}\text { Low } \\
\text { Consecutive }\end{array}$ & $\begin{array}{l}\text { Low } \\
\text { IQCODE-N, } \\
\text { MMSE }\end{array}$ & $\begin{array}{l}\text { Low } \\
\text { CAM, DRS-R98 }\end{array}$ & High & Low & Low & No & $\begin{array}{l}\text { Patients part of negative clinical } \\
\text { trial } \\
\text { Paired serum but different assay }\end{array}$ \\
\hline $\begin{array}{l}\text { Cape(Cape et al., } \\
\text { 2014) } \\
\text { IL-1 } \beta, \text { IL-1ra }\end{array}$ & $\begin{array}{l}\text { High } \\
\text { Opportunistic }\end{array}$ & $\begin{array}{l}\text { Low } \\
\text { IQCODE for } 2 / 3 \\
\text { proportion }\end{array}$ & $\begin{array}{l}\text { Low } \\
\text { DSM-IV using } \\
\text { CAM }\end{array}$ & High & Low & Low & No & Paired serum \\
\hline $\begin{array}{l}\text { Poljak(Poljak et al., } \\
\text { 2014) } \\
\text { Proteomics }\end{array}$ & $\begin{array}{l}\text { High } \\
\text { Sydney: } \\
\text { enrolment offered } \\
\text { on investigation } \\
\text { for prolonged }\end{array}$ & $\begin{array}{l}\text { Low } \\
\text { IQCODE }\end{array}$ & $\begin{array}{l}\text { Low } \\
\text { Sydney: CAM, DI } \\
\text { Edinburgh: CAM, } \\
\text { DRS-R98 }\end{array}$ & High & Low & Low & No & $\begin{array}{l}\text { Selective outcome reporting; } \\
\text { proteomics analysis, so may not } \\
\text { discuss all results } \\
\text { No paired serum }\end{array}$ \\
\hline
\end{tabular}




\begin{tabular}{|c|c|c|c|c|c|c|c|c|}
\hline & $\begin{array}{l}\text { delirium on } \\
\text { clinical grounds } \\
\text { Edinburgh: } \\
\text { opportunistic }\end{array}$ & & & & & & & \\
\hline $\begin{array}{l}\text { Beishuizen(Beishui } \\
\text { zen et al., 2015) } \\
\text { S100B }\end{array}$ & Unclear & $\begin{array}{l}\text { Low } \\
\text { IQCODE }\end{array}$ & $\begin{array}{l}\text { Unclear } \\
\text { DSM IV diagnosis } \\
\text { from medical } \\
\text { records, ?no } \\
\text { formal testing }\end{array}$ & High & Low & Low & No & No paired serum \\
\hline $\begin{array}{l}\text { Westhoff(Westhoff } \\
\text { et al., 2015) } \\
\text { Proteomics }\end{array}$ & $\begin{array}{l}\text { Low } \\
\text { Consecutive }\end{array}$ & $\begin{array}{l}\text { Low } \\
\text { IQCODE }\end{array}$ & $\begin{array}{l}\text { Low } \\
\text { Derivation } \\
\text { cohort: CAM } \\
\text { Validation cohort: } \\
\text { DOSS followed by } \\
\text { DSM IV diagnosis } \\
\text { by psychiatrist }\end{array}$ & Low & Low & Low & No & $\begin{array}{l}\text { Selective outcome reporting; } \\
\text { proteomics analysis, so may not } \\
\text { discuss all results } \\
\text { Derivation cohort part of } \\
\text { negative clinical trial } \\
\text { Preoperative delirium excluded } \\
\text { No paired serum }\end{array}$ \\
\hline $\begin{array}{l}\text { Hall(Hall et al., } \\
\text { 2016) }\end{array}$ & $\begin{array}{l}\text { High } \\
\text { Oslo: consecutive }\end{array}$ & $\begin{array}{l}\text { Low } \\
\text { IQCODE }\end{array}$ & $\begin{array}{l}\text { Low } \\
\text { CAM, MDAS } \\
\text { (retrospective in }\end{array}$ & Low & Low & Low & No & $\begin{array}{l}\text { Oslo patients part of a negative } \\
\text { clinical trial }\end{array}$ \\
\hline
\end{tabular}




\begin{tabular}{|c|c|c|c|c|c|c|c|c|}
\hline Neopterin & $\begin{array}{l}\text { Edinburgh: } \\
\text { opportunistic }\end{array}$ & & $\begin{array}{l}\text { Edinburgh from } \\
D R S-R 98)\end{array}$ & & & & & Paired serum \\
\hline $\begin{array}{l}\text { Hirsch(Hirsch et } \\
\text { al., 2016) } \\
\text { Cytokines }\end{array}$ & $\begin{array}{l}\text { High } \\
\text { Opportunistic }\end{array}$ & $\begin{array}{l}\text { High } \\
\text { Impaired } \\
\text { cognition } \\
\text { excluded, no } \\
\text { inforrmant history } \\
\text { or IQCODE }\end{array}$ & $\begin{array}{l}\text { Low } \\
\text { CAM }\end{array}$ & High & Low & Low & No & $\begin{array}{l}\text { Only } n=1 \text { with delirium (pilot } \\
\text { study) } \\
\text { Paired serum }\end{array}$ \\
\hline $\begin{array}{l}\text { Hov(Hov et al., } \\
\text { 2016) } \\
\text { BBB }\end{array}$ & $\begin{array}{l}\text { Low } \\
\text { Consecutive }\end{array}$ & $\begin{array}{l}\text { Low } \\
\text { Dementia status } \\
\text { according to } \\
\text { consensus of an } \\
\text { expert panel }\end{array}$ & $\begin{array}{l}\text { Low } \\
\text { CAM, MDAS }\end{array}$ & Low & Low & Low & No & $\begin{array}{l}\text { Patients part of a negative } \\
\text { clinical trial } \\
\text { Paired serum }\end{array}$ \\
\hline $\begin{array}{l}\text { Neerland(Neerland } \\
\text { et al., 2016) } \\
\text { IL-6, CRP }\end{array}$ & $\begin{array}{l}\text { High } \\
\text { Oslo: consecutive } \\
\text { Edinburgh: } \\
\text { opportunistic }\end{array}$ & $\begin{array}{l}\text { Low } \\
\text { IQCODE }\end{array}$ & $\begin{array}{l}\text { Low } \\
\text { CAM, MDAS } \\
\text { (retrospective in } \\
\text { Edinburgh from } \\
\text { DRS-R98) }\end{array}$ & Low & Low & Low & No & $\begin{array}{l}\text { Oslo patients part of negative } \\
\text { clinical trial } \\
\text { Paired serum }\end{array}$ \\
\hline $\begin{array}{l}\text { Watne(Watne et al., } \\
\text { 2016) } \\
\text { Aromatic amino } \\
\text { acids }\end{array}$ & $\begin{array}{l}\text { High } \\
\text { Consecutive } \\
\text { recruitment but } \\
\text { groups selected }\end{array}$ & $\begin{array}{l}\text { Low } \\
\text { Dementia status } \\
\text { according to } \\
\text { consensus of an } \\
\text { expert panel }\end{array}$ & $\begin{array}{l}\text { Low } \\
\text { CAM }\end{array}$ & Low & Low & Low & No & $\begin{array}{l}\text { Patients part of a negative } \\
\text { clinical trial } \\
\text { Paired serum }\end{array}$ \\
\hline $\begin{array}{l}\text { Idland(Idland et al., } \\
\text { 2016) } \\
\text { Amyloid, tau }\end{array}$ & $\begin{array}{l}\text { Low } \\
\text { Consecutive }\end{array}$ & $\begin{array}{l}\text { Low } \\
\text { Dementia status } \\
\text { according to } \\
\text { consensus of an } \\
\text { expert panel }\end{array}$ & $\begin{array}{l}\text { Low } \\
\text { CAM }\end{array}$ & Low & Low & Low & No & $\begin{array}{l}\text { Patients part of a negative } \\
\text { clinical trial } \\
\text { No paired serum }\end{array}$ \\
\hline
\end{tabular}

Table 3 Summary of assessment of risk of bias and additional comments on study quality

5-HIAA - 5-Hydroxyindole-acetic acid. AA - Anticholinergic Activity. AChE - Acetyl-cholinesterase. AD - Alzheimer's Dementia. BBB - blood-brain barrier. BLI - Beta Endorphin-like immunoreactivity. CAM - Confusion Assessment Method. DOSS - Delirium Observation Screening Scale. DRS-R98- Delirium Rating Scale - Revised. DSM - Diagnostic and Statistical 
Manual of Mental Disorders. HVA - Homovanillic acid. IL - interleukin. IQCODE - Informant Questionnaire on Cognitive. Decline in the Elderly. MDAS - Memorial Delirium Assment Scale. NSE - Neuron-specific enolase. S100B - S100 calcium-binding protein B. SLI - Somatostatin-like immunoreactivity.

\begin{tabular}{|c|c|}
\hline Planning and consent & $\begin{array}{l}\text { Proposals, information sheets and consent forms should be written to allow for future collaborations } \\
\text { between centres, including transfer to and storage and analysis of samples within another centre, and } \\
\text { future biomarker analyses. Broad and enduring consent is essential. }\end{array}$ \\
\hline Governance & $\begin{array}{l}\text { Local legal arrangements for sample storage needs to be considered and time permitted for Material } \\
\text { Transfer Agreements and Collaboration Agreements to be drawn up }\end{array}$ \\
\hline CSF collection, handling and storing & $\begin{array}{l}\text { Freezer space needs to be planned in advance. Collection volumes and collection container type and } \\
\text { volume, storage aliquot volumes and container type and size should be decided in advance. Aliquot } \\
\text { volumes, and sample organisation, should be considered in advance aiming to minimise freeze-thaw } \\
\text { cycles. Sample transfer to the laboratory for processing should be as swift as possible, and ideally } \\
\text { within } 2 \text { hours. A potential centrifugation protocol of } 2000 \mathrm{~g} \text {, for } 10 \text { minutes, at room temperature } \\
\text { could be considered. Samples should be stored at }-80^{\circ} \mathrm{C} \text {. Polypropylene tubes are recommended and } \\
\text { efforts should be made to use the same brand of containers throughout. Transfer methods, eg dry ice } \\
\text { and courier services, may also need considered. }\end{array}$ \\
\hline Blood samples & Ideally matched serum/plasma and DNA samples should be collected alongside CSF samples. \\
\hline Reporting & $\begin{array}{l}\text { Methods used should be consistent and explicitly reported. } \\
\text { Specifically, time of day, fasting status, needle used, volume and material of collection vessels used, } \\
\text { including manufacturer, method of sampling ie aspiration vs drop collection, volume of CSF collected, } \\
\text { time and temperature to centrifugation, centrifugation details, storage vessel used, aliquot volume, } \\
\text { storage temperature and number of freeze-thaw cycles should be reported. Ideally coefficients of } \\
\text { variation should be reported. }\end{array}$ \\
\hline Collection of clinical data & $\begin{array}{l}\text { Reliable and valid delirium assessment against standard criteria using a validated tool is essential, with } \\
\text { a preference for collecting additional detail: cognitive testing with reporting of scores and/or } \\
\text { untestability; level of arousal measurement; assessment of psychotic features and motoric status; } \\
\text { documentation of presumed aetiologies including potential drug toxicity; assessment of delirium } \\
\text { severity. Information regarding dementia status is particularly important. In elective studies, patients } \\
\text { should undergo objective cognitive testing before sampling of CSF. In studies recruiting acutely } \\
\text { admitted patients, questionnaires such as the Informant Questionnaire on Cognitive Decline in the } \\
\text { Elderly (IQCODE) can be used to assess dementia status. }\end{array}$ \\
\hline
\end{tabular}




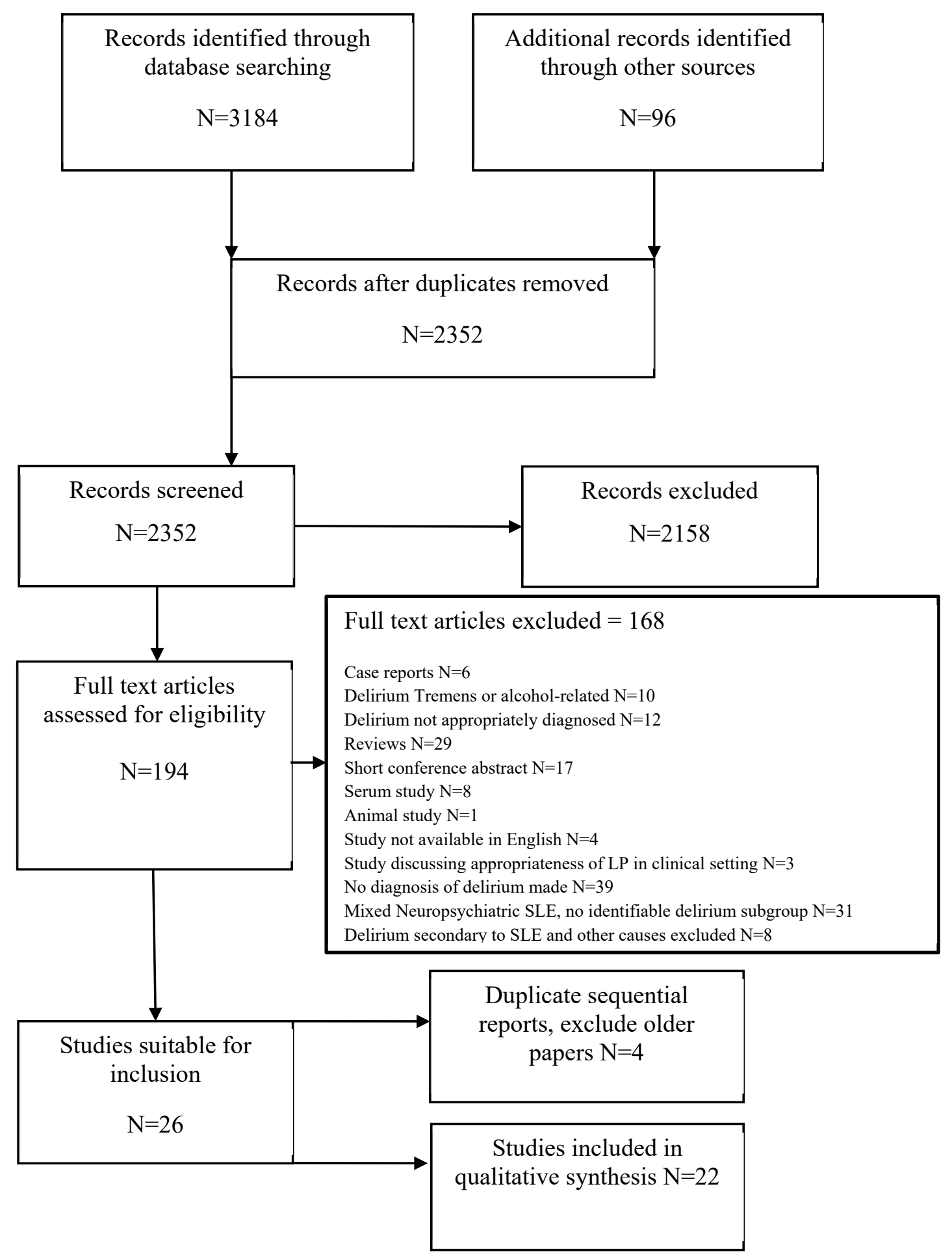

Figure 1 